NBSIR 88-3698 PUBLICATIONS

\title{
A Review of U.S. Participation in International Standards Activities
}

Patrick W. Cooke

U.S. DEPARTMENT OF COMMERCE

National Bureau of Standards

Office of the Associate Director for Industry and Standards

Office of Standards Code and Information

Gaithersburg, MD 20899

January 1988

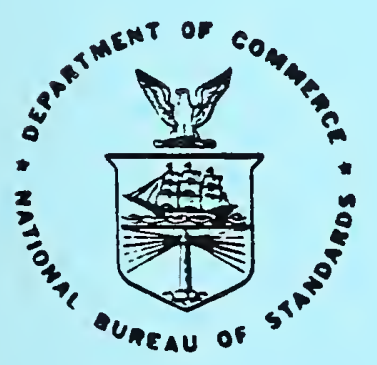

U.S. DEPARTMENT OF COMMERCE

NATIONAL BUREAU OF STANDARDS

$-Q C$

100

.456

$88-3698$

1988

C. 2 


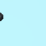




\section{A REVIEW OF U.S. PARTICIPATION IN INTERNATIONAL STANDARDS ACTIVITIES}

Patrick W. Cooke

U.S. DEPARTMENT OF COMMERCE

National Bureau of Standards

Office of the Associate Director for Industry and Standards

Office of Standards Code and Information

Gaithersburg, MD 20899

January 1988

U.S. DEPARTMENT OF COMMERCE, C. William Verity, Secretary NATIONAL BUREAU OF STANDARDS, Ernest Ambler, Director 



\section{A Review of U.S. Participation in International \\ Standards Activities}

Table of Contents

Page

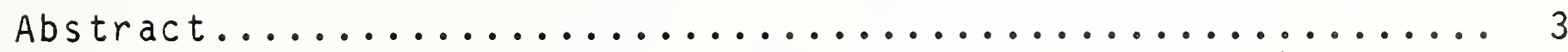

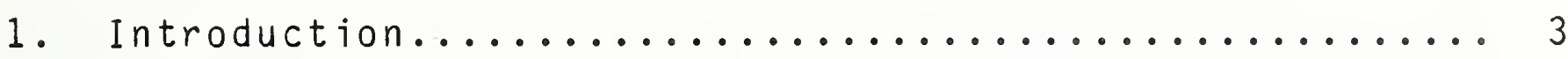

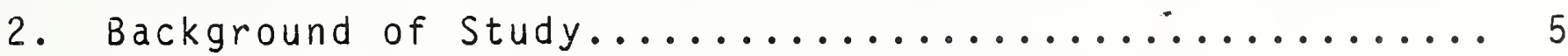

2.1 NBS Responsibilities Regarding Representation

of U.S. Interests in International Standards

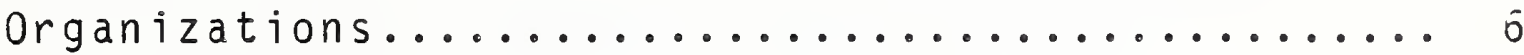

3. Role of International Standards................... 6

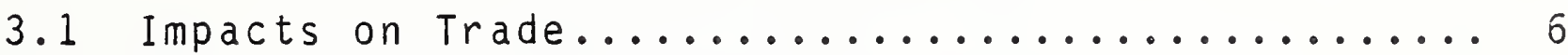

3.2 The Politics of International Standardization.... 7

4. Trends in U.S. International Trade............... 7

5. International Standardization organizations.........8

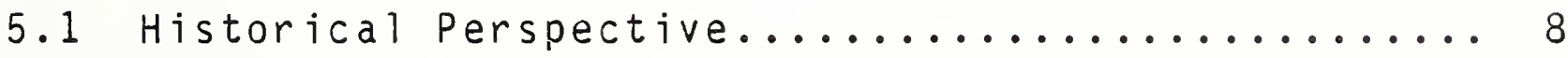

5.2 The International Organization for

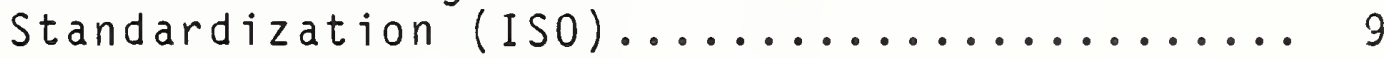

5.3 The International Electrotechnical Commission

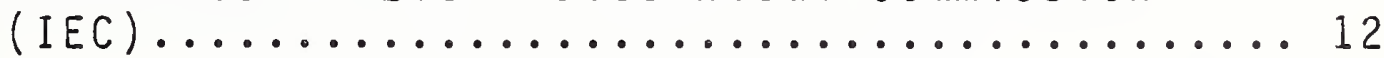

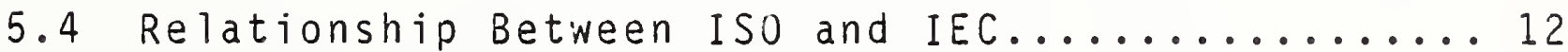

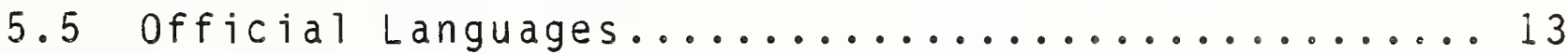

5. 6 0ther International Standardization

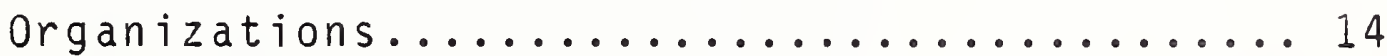

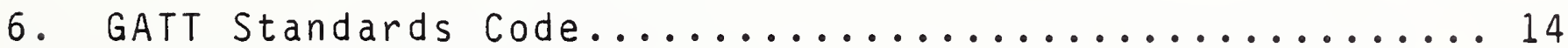

7. Developing Countries and International

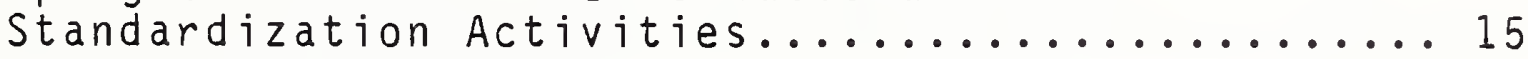

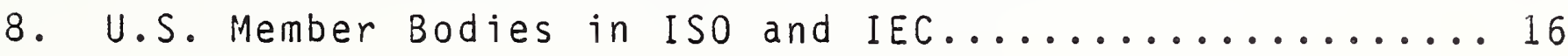

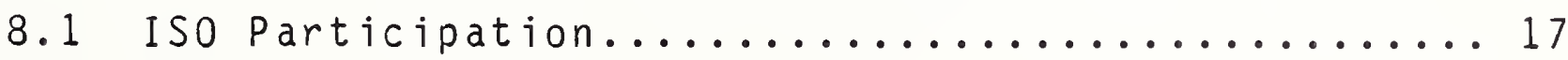




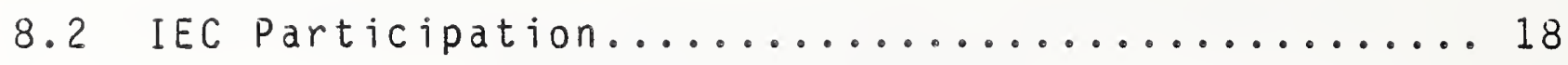

9. U.S. Adoption of International Standards............ 19

9.1 Foreign Use of U.S. Standards.............. 21

10. Summary of U.S. Participation in ISO and IEC ........2 21

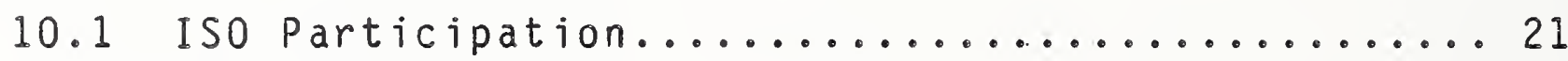

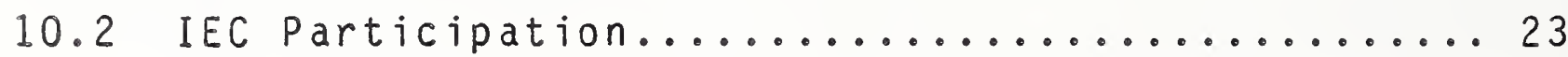

10.3 Comparison of Trade Data with U.S.

Participation in ISO/IEC............... 24

10.4 Major Product Group Trade Performance and U.S.

Participation in ISO/IEC............... 25

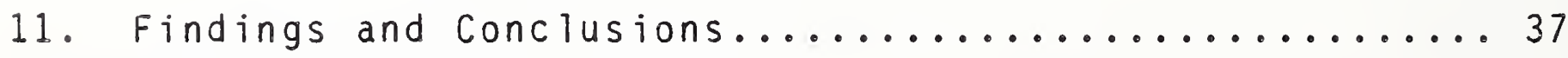

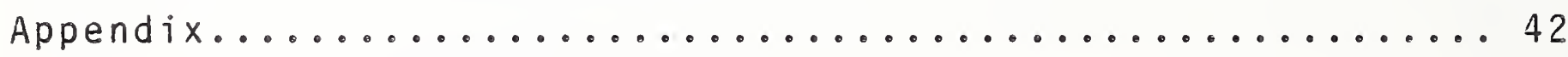

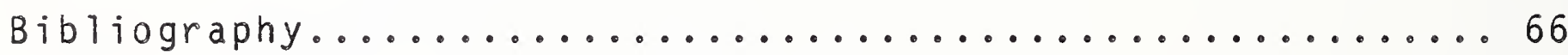




\title{
$\frac{\text { A REVIEW OF U.S. PARTICIPATION IN INTERNATIONAL }}{\text { STANDARDS ACTIVITIES }}$
}

Abstract

Tris report describes the role of international standards, their increasingly significant importance in world trade, and the extent of past and current U.S. participation in the two major international standardization bodies; ISO and IEC. The degree of U.S. participation covers the 20 year period 1966 - 1986 . A coarse analysis of data indicates some correlation between U.S. participation and recent export performance for several major product categories.

\section{Introduction}

\begin{abstract}
"American Industry's lack of participation in helping chart the future course of global standardization may be costing the nation valuable trade dollars that otherwise might wipe out the balance of payments problem. For a leading industrial nation to refrain from participating in global standards work is to state to the rest of the world that either we don't think the items involved are important, or we think we have a design or production method which is superior to everyone else's. We know that neither of these statements is universally true. If we do not become more sensitive to trends and if we are not able to respond quickly, we are inviting serious problems for our economy."
\end{abstract}

The above excerpt is from a speech given at an International Panel on Global Standardization in April 1964 by J. Herbert Hollomon, the then Assistant Secretary of Commerce for Science and Technology. Dr. Hollomon's warning has become in many ways a self-fulfiliing prophecy. Over the past 23 years the United States has become increasingly dependent on international trade, but 'has suffered competitively in the world economy. Our trade balance has turned strongly negative, adversely affecting many of our Nation's industries.

Although there are many and diverse reasons for this decline, U.S. concerns about improving its level of involvement in international standardization activities are as significant today as they apparently were in 1964. On May 5, 1987, the National Bureau of Standards (NBS) and the Department of Commerce's International Trade Administration co-sponsored a Conference on 
Standards and Trade in Washington, D.C.1 The conference objective was to identify how the United States can increase exports by eliminating technical barriers to trade and promote wider international acceptance of standards based on Amei ican technology. Government officials underscored the need to strengthen our trade position, especially by participating in the international standards arena, and warned that our domestic standards will not continue to be accepted worldwide. Conference participants identified a number of standards-related actions that should be addressed to improve the country's trade balance. High on the final agenda were several recommendations for private sector strategies to achieve more effective representation by the United States in organizations that develop international standards.

One of the Administration's major current goals is to "increase America's competitiveness in the world economy." One Department of Commerce subgoal for achieving this national priority is "increasing the acceptance of international technical standards based on U.S. technology."

A report 2 released in August 1987 by the National Academy of Engineering warns that the Nation's scientists and engineers are dangerously unaware of advanced technological developments in other countries and implicates American corporations and universities in the loss of international competitiveness of U.S. industry. The report was prepared for the National Science Foundation (NSF) by a panel of experts from government, industry and academia. It presents ten principal recommendations for improved U.S. efforts to advance its national welfare in a technologically integrated world economy. International standardization participation and the potential benefits to be derived therefrom are the focus of one of these principal recommendations, as follows:

"NSF and other concerned agencies should identify the potential benefits from more assertive and better coordinated U.S. participation in international standards development and in international engineering organizations."

1 Proceedings of Conference on Standards and Trade (NBSIR 87-3573), Walter G. Leight, Editor; National Bureau of Standards, Gaithersburg, MD 20899; June 1987 .

2. Strengthening U.S. Engineering Through International Cooperation: $\frac{\text { Some Recommendations for Action; National Academy }}{\text { of Engineering, Washington, D.C., 1987. }}$ 
An earlier NBS report ${ }^{3}$ described the results of a limited study to assess the extent to which U.S. industry profits by virtue of participation in standards committee activities of international standardization organizations. Although no quantifiable benefits were identified, the results suggested that planned industry activities in international standardization programs are an effective means of producing real economies or for increasing trade. The intangible benefits from active participation--i.e., enhanced markets, informed readiness and economies in operation-. were substantial and could only be achieved via continuing (stable) representation on appropriate international groups by committed industry experts.

This report presents historical information on the extent of U.S. participation and leadership roles (or lack thereof) in the two primary voluntary international standardization bodies, perspectives on the organizations involved, the present role of international standards in world trade, and recommendations for enhancing the U.S. position in international standardization activities and in world trade.

\section{Background of Study}

U.S. participation in non-treaty international standardization activities is voluntary. Direct involvement and payment of the associated expenses depend upon the perceived interests of the industries that may be affected by resultant standards. Consequently, some U.S. companies and industries have been very active in international standards-making committees, while others have not participated at all. The objective of this study was to collect, analyze and present data that might summarize on a gross basis the extent of past and present U.S. participation in the activities of the International organization for standardization (ISO) and International Electrotechnical Commission (IEC) over the 20-year period from 1966 through 1986. The information was developed to assess how U.S. involvement and future leadersinip activities should perhaps be modified to reflect the nation's productive capacity and market size and to strengthen the U.S. position in the world economy.

The following sections describe NBS responsibilities, the significance of international standards in world trade, background on the major standardizing bodies and how the U.S. is organized and represented in those bodies. Separate sections briefly describe the GATT Standards code and the activities of

3 Benefits Perceived by U.S. Industry From Participating in International Standards Activities (NBSIR 84-2886), Patrick W. Cooke, National Bureau of Standards, Gaithersburg, MD 20899, September 1984 . 
developing countries with regard to the influence of international standards. A review of U.S. participation levels in ISO and IEC over the 20-year period 1966-1986 is summarized and a comparison of U.S. exports with U.S. participation in ISO and IEC is analyzed in the last section of the report.

2.1 NBS Responsibilities Regarding Representation of U.S. Interests in International Standards Organizations

Title IV (on standards) of the Trade Agreements Act of 1979, under section 413, directs the Secretaries of commerce and Agriculture to keep informed of the adequacy of representation in international standards-related activities and to identify those activities that might substantially affect the commerce of the United States.

Title IV also specifies that the United States should be represented in non-treaty or private international standards organizations (e.g., ISO and IEC) by a recognized "organization member." The American National Standards Institute (ANSI) is the U.S. member body in ISO and IEC. If the Secretary of Commerce or Agriculture is informed by any interested party or determines that U.S. interests are not adequately represented, the cognizant Secretary is to notify the appropriate organization. If, after 90 days, that organization demonstrates its willingness and ability to adequately represent U.S. interests, the Secretary will take no further action. Otherwise, the secretary is to arrange to provide for adequate representation of U.S. interests through the appropriate organization member. There are no guidelines or definitions given for what is deemed to be "adequate" representation of U.S. interests.

The office of the NBS Associate Director for Industry and standards (ADIS) has been assigned responsibility for carrying out several Title IV functions, including the monitoring of adequacy of representation of U.S. interests in international standards activities, particularly with regard to the potential impact on international trade.

3. Role of International Standards

$3.1 \quad$ Impacts of Trade

International standards are more important today than ever before. In the international marketplace, standards developed through voluntary processes are highly desirable because they represent a broad-based consensus of all interested parties-producers (exporters), users (importers), governments, ultimate consumers and academia. Those nations that actively participate in developing international standards may be able to influence the provisions to favor products which they produce or which they prefer for their own particular national or common-market 
benefits. Since trading countries competing in the global marketplace are inclined to be aggressive in exploiting every opportunity to favor their products via the standards development process, it seems imperative that the United States also participate vigorously in international standardization activities if it intends to maintain existing trade outlets and find new markets. In terms of economic development, market size, and access to that market, the United States ranks in the forefront among the world's industrialized nations. But in the areas of export of manufactured goods and the resulting trade balances, the United States has not kept pace with other developed countries, and is further threatened by newly industrializing countries (NIC's). Much of the reason for this decline in U.S. exports has been attributed to economic factors (i.e., the strength of the U.S. dollar vs. other currencies, the lure of low-cost labor, and government subsidies overseas), but some of the loss may well be due to limited participation and a decline of U.S. influence in the development of international standards.

\subsection{The Politics of International Standardization}

International trade has become an increasingly important factor in the growth of the world economy. The negotiation and adoption of technical standards for all classes of products and services takes on many roles in the global arena - much more than the mere documentation of technical criteria to facilitate the exchange of goods and services among nations. These roles can take such forms as formation of economic and political coalitions among nations and regions, market segmentation among major producers, and even social change among different cultures. National and regional groups have competing interests, and they intervene or use regulations and standards for political purposes. This is particularly true with respect to advancing new technologies. Standards can be invoked to act as non-tariff barriers, protecting one country's industry or new technology from other countries'. Differences in technical standards can be effectively manipulated by governments to segment markets.

The object of international standardization and relatod activities is to facilitate international exchange of goods and services, and to promote cooperation in the sphere of intellectual, scientific, technological and economic activities.

4. Trends in U.S. International Trade

International trade activity has grown steadily in importance (to the U.S. economy) since World War II. However, domestic production and the fraction of that production which was exported both peaked in 1980 and declined steadily until the very recent past. 
The U.S. trade balance for goods and services was positive during most years in the last two decades. Small negative balances in 1977 and 1978 were primarily related to strong growth of the U.S. economy and large increases in the price of imported oil. However, the U.S. trade balance improved and provided a peak surplus of $\$ 28$ billion in 1981. Since then, the trade balance has declined rapidly, becoming negative in 1983 and reaching a deficit of $\$ 64$ billion in 1984 .

In 1985 the United States registered a record trade deficit of $\$ 148.5$ billion, and in 1986, for the fourth consecutive year, our trade deficit set a record at or near $\$ 170$ billion. The United States continues to be by far the largest international trader; however, the U.S. share of total world trade has been declining since 1980 even though a strong U.S. dollar biases dollardenominated measurements upward. In 1985, the U.S. share of total world merchandise exports in dollar terms edged down to 11.4 percent from 11.5 percent the previous year and after a high of 18.0 percent in 1960 (see Figure 1 in Appendix). At the same time the U.S. share of world imports continued to increase, reaching 17.6 percent in 1985, following 17.1 percent in 1984 , as indicated in Figure 1.4

The dollar value of U.S. exports declined by 2.2 percent in 1985 , to a level 8.8 percent lower than the 1981 peak. Measured in local currencies, West German exports increased over the same period about 35 percent and Japan's about 25 percent (see Figure 2): Nevertheless, the U.S. total in terms of dollars is still about 20 percent greater than those of West Germany and Japan though the gap has been narrowing rapidly. Figure 3 indicates that at $\$ 375$ billion, U.S. imports were 128 percent larger than those of West Germany, which still is the second-ranking world importer, and 177 percent larger than those of third-ranking Japan.

5. International Standardization Organizations (Non-Treaty Organizations)

\subsection{Historical Perspective}

International standardization started 80 years ago in the electrotecinical field. While some attempts were made in the 1930's to develop international standards in other fields, it was not until the Forties that significant efforts were devoted to international standardization. During the Fifties and Sixties, international standards work was devoted almost entirely to the development of international agreements on standards of a basic

4 "United States Trade Performance in 1985 and Outiook," U.S. Department of Commerce, International Trade Administration, October 1986. 
nature, with all other standardization remaining at the national level. Those early international standards efforts primarily addressed issues for harmonizing internationally the most fundamental procedures and requirements of a technical nature (e.g., interchangeability, vocabularies, standards for units and symbols, etc.). These activities made a strong contribution to the technical rationalization needed for an extension of international commerce. In the late sixties and seventies, growing emphasis was placed on using international standards instead of national standards. Adoption of the GATT Standards Code in 1979 reflected wide acceptance of the concept of relying on international standards for all classes of finished products, materials, and even services (e.g., banking).

In the international standards arena, there are two primary private sector standards development organizations: ISO and IEC. Together, ISO and IEC form the world's largest nongovernmental open forum for voluntary industrial and technical collaboration at the international level.

\subsection{The International Organization for Standardization (ISO)}

ISO, the largest international standards body, was established in 1947 , with an initial membership of 27 national standards institutes. The present ISO is comprised of standards bodies of 89 countries, 74 of which are participating member bodies and 15 are represented by correspondent members (see listing in Table 1 in Appendix). The scope of ISO covers standardization in all fields except electrical and electronic standards, wilch are the responsibility of the International Electrotechnical Commission (IEC). The broad range of subjects addressed by Iso ranges from screw threads to solar energy.

ISo work is carried out through some 2400 technical groups: 164 Technical Committees (TC's), 645 Subcommittees (SC's), and 1536 Working Groups (WG's), which has resulted in the publication of over 6000 ISO standards to date. See Table 2 for the title, number designation, and year of establishment for each ISO Technical Committee (TC). 
More than $70 \%$ of the ISO member bodies 5 are governmental institutions or organizations incorporated by national law. The remainder are non-governmental standards organizations. ANSI, the U.S. member body to ISO, is one of the few private sector member bodies. The U.S. is the only major industrialized nation that has not taken action to provide for government representation in the affairs of ISO. The U.S. system is unique regarding international standards policy--in our pluralistic society, private sector organizations represent U.S. interests in many non-treaty international bodies, including ISO and IEC.

In such matters as budgets, sources of financial support arid functional responsibilities, the national member bodies differ significantly. Annual budgets of ISO member bodies range from less than 1 million to more than 60 million Swiss francs. In many countries, such as Japan, Mexico, Korea and most of the Eastern Bloc (Poland, Yugoslavia, and USSR), the ISO (and IEC) member bodies are fully financed by their central governments. In Canada and in most countries in western Europe and South America, the national members receive a portion of financial support, ranging from $15 \%$ to $90 \%$, from the central government, with the remainder from subscriptions, sales of publications, certification fees, etc. The U.S. Federal Government provides no funding to ANSI for its domestic or international standardization activities. ANSI's sources for funds include publication sales, subscription and membership fees and donations. Travel and other expenses for delegates from other countries are generally paid by governmental institutions or organizations incorporated by national law (e.g., BSI in the United Kingdom or AFNOR in France), whereas ANSI does not pay such expenses for U.S. delegates to international standards committee meetings.

Tradition, the level of industrialization, the political and legal system, and other factors shape national standardization policies and activities and account for the marked differences in the approach and organizational settings from country to country.

5 A "member body" of ISO is the national body "most representative of standardization in its country." Member bodies are entitled to participate and exercise full voting rights on any technical committee of ISO, are eligible for council membership and have seats in the General Assembly. A "correspondent member" is normally an organization in a developing country which does not yet have its own national standards body or may not have the resources to participate. correspondent members do not take an active part in the technical work nor can they vote, but are entitled to be kept fully informed about the work of interest to them. They may attend the General Assembly as observers. Nearly all the present correspondent members are governinental institutions. 
The responsibilities of national standards bodies also differ from country to country. For example, metrology is regarded as a part of standardization in 37 countries with ISO member bodies, while this activity is the responsibility of other institutions in other countries. Likewise, certification and quality control are primary tasks within many national standards bodies, but not others. Table 3 in the Appendix compares information on budgets, resources, and responsibilities for the top $10 \mathrm{U} . \mathrm{S}$. trading partners which have ISO member bodies.

The ISO central Secretariat in Geneva, Switzerland, helps to coordinate ISO operations, administers voting and approval procedures, and publishes international standards.

Any member body that wishes to participate in the work of any of the 164 Technical Committees may do so. Member organizations which decide to take an active part in the work of a Technical Committee or Sub-Committee are known as "p" (participating) members of that committee or sub-committee; they have an obligation to participate in meetings and to vote. One of the pmembers is designated to act as the secretariat of the committee or sub-committee. Those nations that wish only to be kept informed of the work of a Technical Committee or sub-committee are called "O" (observer) members. They have the right to attend meetings as observers, but not to vote. A request to study a technical subject may be initiated by one or more member bodies or by an organization outside ISO. If at least five members are willing to take an active part, a new technical committee will be formed.

Technical specifications for proposed standards are generally developed by Working Groups (WG), which are given responsibility for specific issues. The Working Group's conclusions are presented to the Subcommittee (SC) in a Draft Proposal (DP). If approved by the Subcommittee, the DP becomes a Draft International Standard (DIS) for ballot by the Technical Committee (TC) with overall responsibility for the subject area. If the ballot is successful, the DIs is then published as an International Standard carrying the same number originally assigned to the DP. Although approval by a TC need not be unanimous, every effort is made to resolve any negative votes. If more than two negative votes remain, it is unlikely that the DIS will be adopted as an International Standard.6 Each ISO International Standard lists the countries that have approved or disapproved. The entire balloting process often takes anywhere

6 When the subject in question is still under technical development or where for any other reason there is the possibility of an agreement at some time in the future, the TC may decide that the publication of a Technical Report would be more appropriate. 
from 18 to 36 months. Several ballots may be taken at the DP and DIS level before agreement is reached.

\subsection{The International Electrotechnical Commission (IEC)}

IEC, also based in Geneva, Switzerland, was formed in 1906 . The present IEC is composed of 42 National Committees whose countries collectively represent some $80 \%$ of the world's population that produces and consumes $95 \%$ of electric energy (see listing in Table 1 in Appendix). The objective of IEC is to promote international cooperation on all questions of standardization in the fields of electrical and electronic engineering. The member "national committees" are required to be as representative as possible of all electrical-related interests in their countries: manufacturers, users, governmental authorities, educational and professional bodies. They are composed of delegates from the various organizations that deal with electrical standardization at the national level. Most committees are recognized and supported by their governments.

The U.S. participates in IEC through the U.S. National Committee of IEC, which is administered by ANSI.

For countries where no National Committee has yet been established, the IEC operates a Registered Subscribers' Scheme. This enables subscribers, such as electric power supply companies, manufacturing enterprises, telecommunication authorities and national standards bodies, to keep abreast of developments in international electrotechnical standardization without participating as voting members.

The work of the IEC is carried out by 80 Technical Committees and 124 Sub-Committees, each responsible for developing standards for a well-defined sector of technology (e.g., TC 64D on Electromedical Equipment). The current committees span a wide range of electrotechnical sectors. (See Table 4 for the title and number designation of each IEC Technical Committee (TC) and Sub-Committee (SC).)

Some 1800 international standards have been developed by IEC. The growth in the cumulative number of IEC standards published and available during the period 1966 through 1986 is shown graphically in Figure 7 .

\subsection{Relationship Between ISO and IEC}

ISO and IEC have a formal agreement establishing a nonduplicative and cooperative relationship between the two organizations. In accordance with this agreement, the two organizations complement each other in the field of international standardization. 
Questions related to international standardization in the electrical and electronic engineering fields are the responsibility of IEC; other subject areas are the responsibility of ISO. In matters of international standardization not related to any particular technology, Iso undertakes the work in ccnsultation with IEC to safeguard any electrotechnical interests which may be involved. To ensure the necessary technical coordination, ISO and IEC have established a joint ISO/IEC Technical Programming Committee. Various liaisons have been established between individual ISO and IEC technical committees.

The two organizations have significantly different structures and operational procedures, some due to historical developments and the normal segmenting of major engineering disciplines, along with a measure of organizational independence.

IEC has substantially fewer members than ISO. Whereas IEC essentially comprises the industrialized and newly industrializing countries, a number of lesser developed countries belong to ISo even though they may seldom participate in specialized technical work. (See Table 1, which lists each country's membership status.)

As for working procedures, the two organizations distribute tasks differently between the official staffs in Geneva and the secretariats of technical committees and subcommittees. ISO committee secretariats do most of their own work (e.g., distribution of documents, preparation of minutes of meetings, duplicating, etc.) during the deliberative stages of standards development. IEC secretariats rely heavily on the central office staff in Geneva for such support.

ISO and IEC have recently undertaken new proposals to harmonize their procedures and methods of work. Some of the new ISO/IEC harmonized procedures were approved during 1987.

\subsection{Official Languages}

The official languages of ISO and IEC are English, French, and Russian. Documents are developed and distributed in both English and French. TC and SC meetings may be conducted in both English and French; WG meetings generally are not bilingual. The member body for the USSR provides all interpretation and translation into or from the Russian language. 


\subsection{Other International Standardization Organizations}

In addition to ISO and IEC, more than 165 other international organizations develop and publish international standards 7 . Standards are also developed and issued by private regional organizations. International and regional standards organizations adopt their own membership rules, which may or may not permit representation by or from the United States.

About 25 international treaty organizations are concerned with standards, two of which are of primary importance in world trade.

- The Treaty of the Meter, adopted in 1875, harmonizes measurement standards among virtually all developed nations. This treaty provides for the establishment and maintenance of a permanent International Bureau of Weights of Measures (located near Paris, France), under the control of an international committee elected by the General Conference on Weights and Measures.

- The International Organization of Legal Metrology (OIML) is an intergovernmental organization, created in 1955, with the main scope of harmonizing and coordinating on the international level the administrative and technical regulations on measurements and measuring instruments issued in various countries.

\section{GATT Standards Code}

Differences between nations' standards, product testing and approval procedures, and certification systems often inder the free flow of goods in international commerce. In 1979, as part of the Tokyo Round of Multilateral Trade Negotiations, the Agreement on Technical Barriers to Trade -- "The Standards Code"-was concluded, the first international agreement recognizing the importance of standards-related activities in international trade. The code is designed to eliminate the use of standards and certification systems as barriers to international trade by establishing a framework of common rules. It does not attempt to create standards for individual products, nor to set up specific testing and certification systems. The code does promote the adoption of relevant international standards as a basis for new national standards and encourages signatories to participate in international standardization organizations with a view towards harmonizing technical regulations of the signatory countries. The Code does not restrict a nation's right to adopt standards or certification systems which are necessary to protect human,

7 NBS Special Publication SP-649, "Directory of International and Regional Organizations Conducting Standards Related Activities," April 1983. 
animal or plant life or health, or the environment; or to prevent the use of deceptive practices.

Each GATT Standards Code signatory must notify the GATT Secretariat of any draft mandatory standard or certification system that might have a significant impact on trade, allow for a comment period on the proposal, and take those comments into account. Each signatory must also establish an inquiry point to respond to inquiries from other signatories concerning standards and certification systems in effect. Most important, signatories are prohibited from adopting standards or certification systems that discriminate against foreign products. Table 1 lists the countries that have signed the GATT Standards code.

The Code applies to both agricultural and industrial products. It does not apply to standards involving services, technical specifications included in government procurement contracts, nor standards established by private companies for their own use. The Code encourages, but does not require, signatories to enter into arrangements for the mutual acceptance of test data.

7. Developing Countries and International Standardization Activities

In recent years, more and more countries have engaged in the work of international standardization. When ISO started in 1947 , approximately $80 \%$ of the 26 member bodies were from the industrialized countries of the world. Even today, the ISO and IEC technical work is based almost exclusively on the experience and knowledge of industrialized countries, and will probably remain that way in the future. But more and more developing countries have an interest in ISO and IEC; these countries now actually constitute the majority (65\% counting correspondent members) of the ISO membership. (See Table I for listing by country groups.)

The contributions of developing countries to the technical work of ISO and IEC may be limited, but these countries are greatly interested in the resultant international standards as they become available. Standards represent a politically and economically neutral transfer of technology of significant importance to them. This is a primary reason why developing countries adopt international standards. Developing countries lack the industrial and economic infrastructure needed to establish their own standards development system, so they look to ISO/IEC to broaden their limited industrial and technological base in their evolving international trade activities.

The emergence of developing countries illustrates the interrelationship of international standards activities and trade opportunities. Industrialized countries, primarily those in Western Europe, have recognized the direct relationship between 
their export trade and the standards developed or adopted in developing countries. Many European nations have moved quickly to help standards-making bodjes of other nations develop their standards and standards-related activities. In the process, they nave provided a bias favoring their own economic position. In a recent report8, an official of the Brazilian Technical Standards Association ( $A B N T$ ) indicated that Brazil maintains close working relationships with the French and German national standards organizations: France and Germany are the most active of all nations in both ISO and IEC. If U.S. interests are not adequately represented in international standardization forums, then there is great danger that specifications written for procurements by developing nations will be less favorable to the U.S. in rapidly growing markets. This concern becomes more significant as the world economy encourages a progressively protectionist attitude toward trade matters.

The GATT Standards Code provides for technical assistance to be given by industrialized member bodies to other code signatories upon mutually agreed terms and conditions. Such assistance may consist, for example, of advice on how to establish a national standards institute or a product certification system. Recognizing that developing countries may face institutional or infrastructural problems in preparing and applying technical regulations, standards, test methods, and certification systems, the code provides for special and differential treatment for developing countries. Developing countries that wish to join the Code may even request specific, time-limited exceptions from certain code requirements.

8. U.S. Member Bodies in ISO and IEC

The American National Standards Institute (ANSI) and the United States National Committee of the International Electrotechnical Commission (USNC/IEC) are the U.S. members of ISO and IEC. Technically, the USNC is an independent organization; however, it is attached to ANSI through its Electrical and Electronics Standards Board. ANSI was formed in 1918 and evolved through many forms until it adopted its present form and name in 1969.

ANSI is a private sector non-profit federation (chartered in the State of New York) of some 240 technical, professional and trade organizations interested in standards. Standards developed by these organizations are designated as national or "American National Standards" after ANSI determines that they have been

8 "Standards Writing in Brazil" by Alberto Cotrim; ASTM Standardization News, January, 1987, p. 42. 
approved in accordance with its consensus procedures ${ }^{9}$. Thus ANSI acts as a coordinating agency for voluntary standardization activities in the U.S. For example, a product standard developed by members of the National Electrical Manufacturers Association, a standard reflecting producer needs and interests, can be processed through ANSI procedures, which require that the views of consumers and users are considered.

At international standards committee meetings, important decisions are made affecting the characteristics (e.g., acceptance criteria, test methods, design and/or performance, interchangeability, etc.) of many products or technologies. In these deliberations, delegations from most other countries, represent their governments' official positions and negotiate accordingly. The U.S. delegates have no official government standing, but generally represent public interest views.

\subsection{ISO Participation}

ANSI coordinates U.S. participation in ISO Technical Committees through technical advisory groups--TAGs--which are administered by trade associations, technical or professional societies, or government agencies. TAGs develop technical positions and assume responsibility for selecting qualified people to represent U.S. interests at international standardization meatings. ANSI establishes the TAG usually naming as a tecinical advisory group the committee or organization that is developing paralle 1 domestic standards: that group directly represents the materially affected U.S. interests and possesses the required tecinical expertise. ANSI generally appoints the secretariat or sponsor of the national standards-developing group as the TAG administrator.

For example: committees of the Society of Automotive Engineers (SAE) that develop domestic standards for internal combustion engines, hydraulic braking systems, and other equipment serve as U.S. technical advisory groups for the ISo technical cominittee on road vehicles and its many subcommittees. SAE administers the TAG with its own staff.

ANSI Accredited Committee $\times 3$ on Information Processing Systems is the U.S. TAG for ISO Technical Committee 97, which is producing international standards for information processing. The Computer

9 Summary data reported in NBS Special publication 631 , "Standards Activities of Organizations in the United States," August 1984, indicates that "....as of 1983 approximately 420 non-governmental organizations maintained an estimated 32,000 U.S. voluntary standards. Of this amount, approximately 8,500 standards or $25 \%$ of all the non-governmental standards have been processed through ANSI to be designated as "ANS" or American National Standards." 
and Business Equipment Manufacturers Association (CBEMA), secretariat of the $X 3$ Committee, is the TAG administrator.

Federal agencies administer some technical advisory groups. Thus, the U.S. Geological Survey supervises the development of the U.S. viewpoint for ISO work on measurement of liquid flow in open channels. The National Bureau of Standards administers the TAG for a subcommittee of the ISO committee on industrial automation systems.

ANSI provides technical advisory groups with:

- criteria and procedures to guide them in their operations and in reaching consensus on positions for international standards activities;

- advice from staff and communication on those Iso technical committee and subcommittee matters on which the Institute needs the TAG's recommendations; and

- guidance from ANSI standards boards on coordination between parallel national and ISO international standards.

\subsection{IEC Participation}

The U.S. National Committee of IEC (USNC/IEC) manages U.S. participation in the technical work of the International Electrotechnical Commission. It takes part in the commission's entire technical program and holds secretariats of some thirty technical committees and subgroups. Among them are committees that develop international recommendations for solar photovoltaic energy systems; safety of data processing equipment and office machines; cables, wires, and waveguides for telecommunication equipment; and safety of household and similar electrical appliances.

The USNC appoints a technical advisor and a technical advisory group to develop the U.S. viewpoint for the work of each IEC committee and subcommittee. Advisors are drawn from U.S. professional/technical societies, trade associations, companies, government agencies, and testing laboratories concerned with the development of national electrotechnical standards. The technical advisor develops. the U.S. position on IEC committee matters by consulting with the advisory group. The technical advisor is also responsible for having the U.S. position presented to the appropriate IEC Technical Committee, hence must select knowledgeable delegates and assure that financial support is available for attending IEC meetings. Delegates are selected from U.S. professional/technical societies, trade associations, industrial companies, government agencies and testing 
laboratories that are also involved in the development of national electrotechnical standards.

ANSI provides secretariat services to the USNC, its Executive Committee, technical advisors, and technical advisory groups.

9. U.S. Adoption of International Standards

Through 1987, ISO had published some 6400 standards10 and IEC had published an additional 1800 standards.11 Similar numbers of proposed standards are in various stages of development within each organization.

A large and growing number of ISO and IEC standards are being adopted directly by many countries as national standards. In accordance with ISO/IEC Guide 3 , these are "identical standards" and are identified by the basic international standards number, e.g., BIS-ISO 3506 or DIN/IEC 383. It is difficult to obtain authoritative information on the extent of direct adoption by various countries, but at a 1986 conference on implementing international standards 12 the scale of adoption in selected European countries was reported as follows:

10 As of July 1987,6401 ISo standards were published per the 1987 ISO Catalogue, p. II .

11 Per information provided by IEC and ANSI.

12 Presentation by Gerald A. Price "Implementing International Standards on a Regional Basis; "Joint Standards Engineering Society (SES) and International Federation for the Application of Standards (IFAN) Conference; Philadelphia, October 1986. 
Country

Denmark

France

Nether lands

United Kingdom

Germany (FRG)

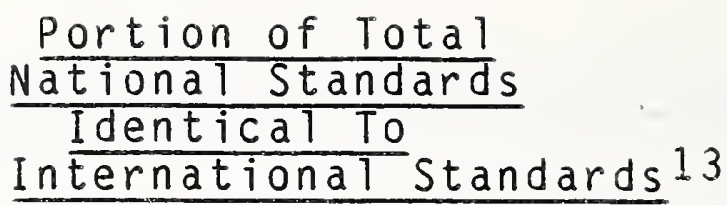

$43 \%$

$37 \%$

$22 \%$

$16 \%$

$5 \%$

Only 15 of the approximately 8500 American National Standards have the designation "ANSI/ISO" to indicate identity with the corresponding international standard. These are in the area of photography and micrographics, and are for the most part U.S. standards that were proposed and subsequently approved as ISO standards. In photographic products, film speeds have been designated as "ISO speed" in place of "ASA speed" since 1982 when the ANSI standard was adopted by ISO (i.e., ANSI/ISO 2240-1982). (See Table 5 for list of ANSI/ISO standards.)

Some countries, such as the U.K., identify degrees of conformity between their national standards and the corresponding international standard. The British standards Institution designates conforming standards as "identical, "technically equivalent" or "related." At a recent GATT Standards Code Committee meeting (october, 1987) it was reported that approximately $40 \%$ of Chinese standards are based on international standards.

National differences can affect the degree of direct adoption of international standards. Different cultures and philosophical traditions and approaches to safety or to regulation may affect the degree of harmonization among national, multi-national, regional and international standards. The differing characteristics of electric current and nominal supply voltages prohibit direct adoption in the U.S. of many IEC Standards which are based on European frequency ( 50 cycles vs. U.S. 60 cycles) and voltages (120/240 volts vs. U.S. 110-225 volts). obviously, the U.S. was not persuasive enough in the development of these IEC standards to have the international standards incorporate or even "accommodate" standard U.S. electrical current characteristics. In the area of product performance, however,

13 It should be pointed out that some international standards are endorsed as national standards as they stand, while others are translated for publication as national standards. As a result, equivalent texts are often available in two or more other languages. Iso standards are always published in both English and French and may be endorsed without change to become an AFNOR (France), DIN (Germany) or SFS (Finland) standard. 
there is opportunity for greater harmonization. Also in the areas of new technology, the opportunities are greater.

\subsection{Foreign Use of U.S. Standards}

The standards of several U.S. organizations are used extensively by traders in other countries and in many cases have become "de facto" international standards. The American Society of Mechanical Engineers (ASME) codes and standards, particularly the ASME Boiler and Pressure Vessel Code, enjoy broad recognition and acceptance around the world. ASTM, the largest U.S. standards writing organization, which concentrates heavily in the areas of petroleum, metals, coal, concrete and plastics, is also recognized worldwide for the high quality of its standards for test methods and material specifications. Many ASTM standards, especially for petroleum products and plastics, have formed the basis for standards issued by promulgated by ISo and regional standards bodies. In 1982, ASTM commissioned a study conducted by Humberside Coliege in Hull, England, to examine the role that standards play in international trade, particularly from the users' perspective.14 That study concluded that, in the five countries surveyed, ASTM standards were either the standards of choice or second only to the national standards.

10. Summary of U.S. Participation in ISO and IEC

10.1 ISO Participation

In 1966, the U.S held ISO secretariats on ten of the 118 technical committees that then existed. These secretariats were as follows:

TC-11, Unification of Boiler Code (U.S. still holds secretariat in 1987)

TC-28, Petroleum Products (U.S. still holds secretariat in 1987)

TC-36, Cinematography (U.S. still holds secretariat in 1987)

TC-42, Photography (U.S. still holds secretariat in 1987)

TC-6I, Plastics (U.S. still holds secretariat in 1987)

TC-66, Determination of Viscosity (This TC has been dissolved)

TC-85, Nuclear Energy (Secretariat now held by Federal Republic of Germany)

TC-97, Computers and Information Processing (U.S. still holds secretariat in 1987 )

TC-104, Freight Containers (U.S. still holds secretariat in 1987) TC-108, Mechanical Shock and Vibration (U.S. still holds secretariat in 1987)

14 See "The Use of ASTM Standards in International Trade;" Parts 1 and 2; ASTM Standardization News, May and June 1984 , ASTM, Philadelphia, PA. 
The U.S. in 1966 had little interest in participating in technical committees on building construction, concrete, mining, rivets, fire safety tests, and textile machinery. These areas were focused domestically, and foreign markets were not then exploited.

Figure 4 indicates that the percentage of ISO secretariats held by the U.S. has remained fairly constant over the last 20 years.

In 1966 the U.S. ranked third, with about 9\% of secretariats, and in 1986 was fourth, with $12 \%$ of Iso secretariats. The United Kingdom, Germany and France hold more TC and SC secretariats then the U.S. today.

In 1986 the U.S. held 16 secretariats of the 164 ISO Technical Committees $(9.8 \%)$ as follows:

TC-11, Boilers and pressure vessels (since 1947)

TC-20, Aircraft and space vehicles (since 1976)

TC-28, Petroleum products and lubricants (since 1947)

$T C=31$, Tires, rims and valves (since 1966)

$T C-36$, Cinematography (since 1947)

$T C-42$, Photography (since 1947)

TC-61, Plastics (since 1947)

TC-68, Banking (since 1972)

TC-97, Information processing systems (since 1960)

TC-104, Freight containers (since 1961)

$T C-108$, Mechanical vibration and shock (since 1963)

TC-127, Earthmoving machinery (since 1968)

TC-131, Fluid power systems (since 1969)

$T C-153$, Valves (since 1984)

TC-161, Control and safety devices for heat generating systems (since 1985)

TB-189, Ceramic tile (since 1986)

In 1986, the U.S. held the secretariats for 69 of the 645 subcommittees $(10.7 \%)$ and the U.S. was the convenor of 212 of the 1556 ISO Working Groups (13.6\%). Thus, U.S. held 297 out of the 2365 leadership positions available (12.6\%) within Iso.

The U.S. was designated as an active participant in 113 of 164 (68.8\%) ISO Technical Committees in 1986 and as an "ooserver" for 48. The U.S. was designated as "not represented" in three ISO Technical Committees:

$$
\begin{aligned}
& \text { glass containers } \\
& 0 \text { tobacco and tobacco products } \\
& 0 \text { jewelry }
\end{aligned}
$$

ANSI estimates that in 1986, 466 U.S. delegates participated in 132 ISO standards committee meetings (i.e., TC and SC meetings). The U.S. hosted seven ISO TC and/or SC meetings in this country. U.S. delegates are drawn primarily from private companies (75\%), 
the remainder coming from government, trade associations, and academia.

\subsection{IEC Participation}

Until after World War II, the U.S. electrical industry maintained a largely passive role in the activities of IEC. National standards were more prominent in world trade than the then available international standards.

In the late 1960's and early 1970's, the U.S. electrical industry began to be more active in developing IEC standards. However, the U.S. delegates had limited effectiveness due to lack of delegate continuity, language differences, and limited understanding of European history, culture and traditions. It was a time of frustration and learning. In the meantime, it became clear that the Europeans knew far more than U.S. producers about American customers. They learned our language, studied our markets, and joined our standards-making organizations. They also participated on a long-term basis in the American standards scene with knowledgeable, effective, dedicated representatives.

In the middle 1970's, the U.S. electrical industry made a renewed effort to take a more active role in the IEC. Several firms made experts available for IEC activities. Goals were established, one of which was to introduce U.S. test methods and performance criteria into IEC standards.

A comparison of IEC standards and U.S. standards showed many similarities, especially in concepts of safety criteria. However, in product areas, it was apparent that arbitrary product "design" requirements in IEC standards and U.S. standards made it highly unlikely that compromises could be reached. A new approach was needed to obtain "harmonization, "moving from "design" criteria to "performance-based" criteria. Most IEC participants agreed to this change in direction and work began in earnest. U.S. delegate participation was expanded to include all levels of standards development. U.S. delegates were asked to make at least a three-year commitment for service on IEC committees and subcommittees to assure continuity. U.S. technical advisory groups were enlarged, and U.S. input was provided at each level of IEC standards work.

As indicated in Figure 6, the fraction of IEC TC and SC secretariats held by the U.S: increased from about $9 \%$ in 1966 to $16 \%$ in 1986. Only France with 19\% holds more. In overall ranking, the U.S. was fourth behind the United Kingdom, France and Germany in 1966; in 1986 the U.S. ranked second.

The U.S. currently holds the secretariat for the following IEC TC's and SC's: 
Classification of insulation systems for rotating machinery (since 1981)

Hydraulic turbines (since 1956)

Equipment used in the mobile services (since 1972)

Endurance tests (since 1966)

Semiconductor power converters for adjustable speed electric drive systems (since 1982)

Quantities and units, and their letter symbols (since 1966)

Flameproof enclosures (since 1984)

Apparatus for use in the presence of ignitable dust (since 1960) Surge arresters (since 1966)

Cables, wires and waveguides for telecommunications equipment (since 1971)

Waveguides and their accessories (since 1966)

Connectors for r.f. cables (since 1982)

Electromechanical components for electronic equipment (since 1968 )

Connectors (since 1968)

Printed circuits (since 1985)

Electric dishwashers (since 1966)

Microwave appliances (since 1972)

Safety of household and similar electrical appliances (since 1967)

Safety of household microwave ovens (since 1970)

Appliances for air-conditioning for household and similar purposes (since 1973)

Safety of projectors (since 1983)

Electromedical equipment (since 1970)

Elements of systems (since 1973)

Oscilloscopes (since 1969)

Analyzing equipment (since 1975)

Automatic controls for household use (since 1971)

Safety of data processing equipment and office machines (since 1973 )

Laser equipment (since 1973)

Solar photovoltaic energy systems (since 1982)

Measuring equipment for basic electrical quantities (since 1985)

Radio interference measurements and statistical methods (since 1975)

In 1966 the U.S. held but seven IEC secretariats.

In 1986, the U.S. was represented by 143 delegates at 45 IEC TC and SC meetings. IEC delegates are predominantly from private industry $(85 \%)$, with the remainder from trade associations and government agencies. The U.S. hosted 4 IEC meetings in this country in 1986.

10.3 Comparison of Trade Data With U.S. Participation in ISO/IEC

This section provides a rough evaluation of U.S. participation in ISO/IEC by major product groupings utilizing 1986 U.S. trade data 
obtained from DoC's International Trade Administration. The data compiled in Table 6 ranks 34 major product groups by the dollar value of $1986 \mathrm{U} . \mathrm{S}$. exports. Also shown are the corresponding dollar value for 1986 imports and the resulting trade balance for each product group. These 34 product groups accounted in 1986 for 68 percent of U.S. exports and 71 percent of our imports.

Corresponding ISO and IEC technical standards committees whose work relates directly or indirectly to each major product grouping were identified using various ISO and IEC documents (e.g., catalogues, directories, memento, etc.) Some ISO/IEC committees are active in standards development for more than one product within a single group or, in some cases, relate to more than one product group. Unfortunately, the aggregation of trade data reports and product classification definitions make it extremely difficult to exactly match export product groupings with ISO and IEC standardization committees, especially since many committees concentrate on specific technical disciplines (e.g., acoustics, air quality, mechanical vibration and shock, etc.) rather than products. The data compiled in Table 7 represents the best subjective matching of product groups with the scopes of international standards committees. Information on TC chairmanships held by the U.S. and participant or observer status are also indicated. Similar information for IEC secretariats and chairmanships is presented in Table 8 .

The product groups were divided into four data sets based on export values as presented in Table 9. The corresponding figures for all ISO/IEC secretariats and those held by the U.S. Were also aggregated within their respective data sets. The data on secretariats were also averaged for all product groups covered and the average for U.S. held secretariats to all ISO/IEC committees for 1986 is also indicated. This compilation, although rough in many respects, indicates that U.S. representation and level of effort in ISO/IEC international standardization activities correlates well with trade value, favoring higher technology product groups over those in basic product categories. The largest monetary value export group is made up of but 4 product codes, whereas the smallest monetary value group (and the lowest ISO/IEC secretariat level) is composed of 15 product codes. The average percentage of all U.S. held secretariats for 1986 in ISO/IEC was $12.9 \%$ while the average for the $1986 \mathrm{U} . \mathrm{S}$. held secretariats related to the 33 product categories in the four product groups was $12.6 \%$.

10.4 Major Product Group Trade Performance and U.S. Participation in ISO/IEC

The following discussion provides a group-by-group summary of tine categorization of products within the corresponding two-digit Schedule E Commodity Codes and a synopsis of U.S. participation activities in the corresponding ISO and/or IEC standards 
committees whose technical work directly or indiractly relates to a particular product group. The order of product groups generally follows the 1986 export rankings given in Table 5 .

Commodity Code 73 - Road Vehicles - This group includes passenger cars, trucks, buses, tractors (on-road), motorcycles, bicycles, special purpose vehicles and parts and components for these items.

ISO Technical Committee 22 on Road Vehicles is the major international group concerned with all questions of standardization (e.g., compatibility, interchangeability, safety, test procedures, performance, etc.) for this commodity group. TC 22 also is probably the largest technical body within Iso having 24 separate subcommittees and 77 working groups covering everything from "electrical interferences" to "fuel consumption measurement" to "brake systems and equipment." In 1986 the U.S. held the secretariat for thirteen (13\%) of these 101 subcommittees and working groups. There were 17 less subcommittees and working groups in TC 22 during 1978. The ISO Memento for 1978 indicates that the U.S. held the secretariat for sixteen (or 19\%) of these 84 subcommittees and working groups. This represents a loss of three U.S.-held secretariats within TC 22 during a period of standardization growth and technological change. Germany and France hold a significant number of secretariats in TC 22 .

The other ISO Technical Committee with standardization interests relevant to this product group is TC 149 on Cycles. The U.S. is registered as an "O" member (i.e., "non-voting observer") for TC 149.

Commodity Code 75 - Office Machines and ADP Equipment -- U.S. export trade in this category is dominated by automatic data processing machines and parts of both ADP machines and office machines.

The U.S. maintains a strong position in ISO/IEC standardization activities involved in information technology systems. ISO TC 97 - Information Processing Systems, IEC TC 83 - Information Technology Equipment and IEC SC 47B - Microprocessor Systems are the primary committees working on technical standards relevant to this product group. The activities of these three committees have recently been integrated into the first ISO/IEC Joint Committee ever to be convened. The new joint committee has been designated as "ISO/IEC JTC 1 - Information Technology." The U.S. through ANSI, will administer the international secretariat of JTC 1. The U.S. holds the secretariat of ISO/TC 97 and four of its subcommittees - on open systems interconnection, telecommunications, magnetic media, and text and office systems. It will carry out these same responsibilities under the new ISO/IEC JTC I organization. In IEC, the U.S. also holds the SC 
chairmanship for IEC/SC 47 B - Microprocessor Systems and the secretariat for IEC/TC 74 - "Safety of Data Processing Equipment and Office Machines."

Commodity Code 79 - Transport Equipment -- This category consists mainly of aircraft, although ships, boats, railway vehicles, and trailers are included as well. Aircraft sales constitute the major component of this product group.

ISO has two technical committees with primary interest in this product sector. They are: (1) TC 20 - Aircraft and Space Vehicles, and (2) TC 8 - Shipbuilding and Marine Structures. IEC has activity related to rail transport equipment via TC 9Electric Traction Equipment and other TCS and SCs involved in navigation, instrumentation, lamps, and sinipboard electrical installations. U.S. standards interests are concentrated on aircraft by virtue of its presence in TC 20 where it holds 13 of the 46 secretariats including the TC secretariat. This involvement is the result of a study in the early $1980^{\prime} \mathrm{s}$ by the Aerospace Industries Association to assess the future impact of international standardization on the U.S. aerospace industry. The study resulted in a program to develop a sound industry strategy to play an active leadership role in international standardization activities and to promote the adoption of standards favorable to U.S. technological achievements.

Commodity Code 77 - Electrical Machinery, Apparatus, Appliances and Parts - This commodity class consists of a wide range of electrical equipment including electronic components (e.g., semiconductors), circuit breakers, connectors, electromedical equipment and household appliances.

Standards development at the international level is predominantly within the sphere of the IEC for this product group. Sixty IEC TCS and SCS were identified as having direct or indirect standards programs that impact this category of electrical products and equipment. Of these 60 TCS and SCS, the U.S. holds 10 secretariats and 4 chairmanships. The TC secretariats held are:

(1) TC 61 - Safety of Household and Similar Electrical Appliances. (The U.S. also holds 3 of the 8 SC secretariats and one SC chairmanship in TC 61.)

(2) TC 72 - Automatic Controls for Housenold Use and

(3) TC 52 - Printed Circuits

The only ISO activity to directly affect this product group is TC 86 - Refrigeration. The U.S. holds 3 of the 7 subcommittees secretariats in TC 86. The last plenary meeting was in 1985. 
Commodity Code 71 - Power Generating Machinery -. This product class is largely automotive and aircraft engines and parts, but also contains steam and vapor boilers and generators and electric motors and generators.

Both ISO and IEC have significant standards development activities that impact products in this trade category. U.S. participation levels and leadership roles are well represented in both standards bodies. Among IEC secretariats available, the U.S. holds 3 of the 13 secretariats (23\%) and 4 chairmanships in IEC as follows:

TC 5 - Steam Turbines - secretariat and chairmanship (holding both secretariat and chairman for the same TC or SC in IEC is unusual)

TC 4 - Hydraulic Turbines - secretariat

SC 2J - Classification of Insulation Systems for Rotating Machinery - secretariat

SC $2 A$ - Turbine-Type Generators - chairman

SC $2 G$ - Test Methods and Procedures - chairman

The U.S. holds 10 of the available 58 TC, SC, or WG secretariats in ISO for the following 3 technical committees:

TC 11 - Boilers and Pressure Vessels - U.S. holds the TC and 2 WG secretariats.

TC 70 - Internal Combustion Engines - U.S. holds one SC and one WG secretariat.

TC 85 - Nuclear Energy - U.S. holds one SC and four WG secretariats.

Commodity Code 72 - Specialized Machinery for Particular Industries - This class contains a wide variety of industrial machinery such as agricultural machinery, construction and mining equipment, textile machinery, tractors, and printing and bookbinding equipment.

U.S. international standards interests for this product group are concentrated in the following ISO Technical Committees:

(1) TC 23 - Tractors and Machinery for Agriculture and Forestry - where the U.S. holds 3 SC and 2 WG secretariats from among the 38 such secretariats in place. 
(2) TC 127 - Earthmoving Machinery - where the U.S. holds both
the TC secretariat and chairmanship, and

(3) TC 67 - Materials and Equipment for Petroleum and Natural Gas Industries - where the U.S. holds one SC and tiwo WG secretariats from among 9 available positions.

Among the other standards development activities within ISO with technical work relevant to this trade category, the U.S. is a non-voting observer in the following ISO technical committees:

(1) TC 72

Textile Machinery and Allied Machinery and Accessories (last plenary meeting was in 1985), and

(2) TC 82 - Mining (last plenary meeting was in 1962).

Within IEC, the only directly relevant activity is covered by TC 71 - Electrical Installations for outdoor Sites Under Heavy Conditions (Including Open-Cast Mines and Quarries) where the U.S. holds the chairmanship of the TC.

Commodity Code 74 - General Industrial Machinery, Equipnent and Parts - This is a group of disparate products which includes such items as heating and cooling equipment, pumps, air and gas compressors, fans, mechanical handling equipment, refrigeration equipment and miscellaneous machinery parts.

The technical standardization work of Iso for this diverse product group covers 18 individual technical committees made up of 75 subcominitees and 143 working groups -- the most standards development units for any of the Schedule E Commodity codes. IEC has but two technical committees -. TC 69 - Electric Industrial Trucks and TC 27 -. Industrial Electroheating Equipment - - with direct standards interests bearing on this product group. The U.S. holds $14 \%$ ( 32 of 236 ) of the secretariats and participates in 16 of the 18 ISo technical committees. Within the $18 \mathrm{TCs}$, the U.S. dominates in TC 131 - Fluid Power systems where it holds the TC secretariat, 3 of the 9 SC secretariats, and 10 of the 30 working group secretariats. The U.S. also holds 5 of the 9 SC secretariats in TC 4 - Rolling Bearings but holds no secretariats in TC 123 -. Plain Bearings. In addition to the TC secretariat for TC 13l, the U.S. also holds the TC secretariat as well as the TC chairmanship for the following two TCS:

(1) TC 104 - Freight Containers

(2) TC 153 - Valves

The TCS in which the U.S. is registered as a non-voting observer member are: 
(1) TC 101 - Continuous Mechanical Handling Equipment (last meeting was in 1986), and

(2) TC 128 - Glass Plant, Pipeline and Fittings

(last meeting was in 1975)

Commodity Code 87 - Professional, Scientific, and Controlling Instruments - This group includes various kinds of instruments including optical instruments, medical instruments, meters and counters, surveying instruments, automatic pilots, precision balances, and seismographs.

International standardization activities for this product group cuts across a number of technical committees in both ISO and IEC. Participation levels and leadership roles of U.S. interests are stronger in the IEC committees than in. ISO, although the IEC committees concerned are more high-tech oriented than are the Iso groups. The U.S. holds 3 of 19 secretariats (TC 85 - Fiber optics, SC 65 B - Elements of Systems, and SC 66 D - Analyzing Equipment) and four TC or SC chairmanships in IEC. In ISO, the U.S. holds 4 of 59 SC or WG secretariats and no chairmanships. The Iso technical committees in which the U.S. holds a secretariat are:

(1) TC 172 - 0ptics and 0ptical Instruments; WG 4 - Test instruments and test methods for contact lenses

(2) TC 121 - Anaesthetic and respiratory equipment; SC 3Breathing Machines, and WG 1 - Laryngoscopic Fittings

(3) TC 84 - Syringes for medical use and needles for injection, WG 1 - Reusable syringes and needles.

The U.S. is registered as a non-voting observer member of ISO TC 170 - Surgical Instruments. The last plenary meeting of TC 170 was in 1985. Federal Republic of Germany holds the secretariat of TC 170; there are no subcommittees or working groups listed for TC 170 .

Commodity Code 51 - Organic Chemicals and Related Products-organic chemicals are products mainly derived from petroleum or natural gas, with additional inputs from coal or agricultural products.

For this product group, the U.S. maintains a dominant position in ISo standards work through its long-term leadership roles and active participation in TC 28 - Petroleum Products and Lubricants. The U.S. holds the TC secretariat, two of the six 
subcommittee secretariats and nine of the 24 working group secretariats in TC 28. This high level of participation is diminished by U.S. inactivity in a related committee: TC 47Chemistry where the U.S. is registered as a non-voting observer member.

Commodity Code 76 - Telecommunications and Sound Recording and Reproducing Equipment - This group contains radio and television communications equipment, broadcasting equipment, and detection apparatus, -. items still relatively competitive in export markets - and consumer electronic products, most of which are imported either from foreign firms or from U.S. assembly operations overseas.

International standardization activities for this product group take place in various IEC technical committees and subcommittees. The major IEC Technical Committees are TC 12Radiocommunications, TC 46 - Cables, wires and waveguides for Telecommunication Equipment, TC 60 - Recording, TC 48Electromechanical Components for Electronic Equipment, TC 85Fiber Optics, and several other related subcommittees. The U.S. reportedly participates actively in all 25 of the IEC committees and subcommittees and holds 9 secretariats ( 4 at the TC level and 5 at the Sc level) and 2 chairmanships among the 25 committees.

Commodity Code 53 - Synthetic Resins, Rubber, and Plastic Materials - The U.S. has active participation and leadersinip roles in the ISO Technical committees with international standardization responsibilities for this product group. The U.S. holds the secretariat for TC 61 - Plastics and 10 of the 74 subcommittee and working group secretariats in TC 61 . The U.S. also holds five of the 22 working group secretariats in TC 45Rubber and rubber products.

Commodity Code 54 - Medicinal and Pharmaceutical Products-There are no ISO or IEC standardization activities for this product group. The World Health organization sets standards at the international level for the quality control of drugs, vaccines, and other substances affecting health.

Commodity Code 69 - Miscellaneous Metal Manufactures - This diverse group contains such items as: metal structures (doors, roofing, building sections and shapes); storage and transportation containers; wire products; nails, bolts, etc.; tools; cutlery and flatware; household articles (cookware, sanitary fixtures, etc.); and, safes and locks.

There are an array of ISO Technical Committees whose standardization activities relate to this diverse product group. The U.S. participates in seven of these TCS, holds five subcommittee and working group secretariats in four of these TCS, 
and has a non-voting observer registration in 2 of the TCs. The

TCS on which the U.S. has a secretariat role are:

(1) TC 2 - Fasteners

(2) TC $29-$ Small Tools

(3) TC 100 - Chains and Chain Wheels for Power Transmission and Conveyors

The U.S. is registered as a participant in the following 4 TCS:

(1) TC 105 - Steel wire ropes

(2) TC 111 - Round steel link chains, lifting hooks and accessories

(3) TC 164 - Mechanical Testing of Metals

(4) TC 167 - Steel and Aluminum Structures

The two TCS in which the U.S. is an observer are:

(1) TC 52 - Metal Containers (last meeting in 1985)

(2) TC 186 - Cutlery and Table and Decorative Metal Hollow-ware ( 1 ast meeting in 1984)

Commodity Code 52 - Inorganic Chemicals -- For purposes of trade classifications, inorganic chemicals are elements and compounds produced primarily from chemical processes. Major items in U.S. exports include enriched uranium compounds and sodium salts. Among the largest imports were uranium compounds and alumina.

There are a mix of ISO Technical Committees dealing with various international standardization aspects that directly or indirectly relate to this product group. The more significant TCs are TC 47 - Chemistry, TC 85 - NuClear Energy and TC 79 - Light Metals and their Alloys. The U.S. only holds a "non-voting" observer registration in TC 47 ; in TC 79 the U.S. holds four of the 23 subcommittee and working group secretariats. In TC 85 the U.S. held the overall TC secretariat until 1979 when the Federal Republic of Germany took over the position. In 1986, the U.S. held 5 of the 28 subcommittee or working group secretariats in TC 85 .

Commodity Code 59 - Chemical Materials and Products -- This product group covers various chemical products including pesticides, cornstarch, adhesives, turpentine, gum inhibitors for fuel oil and lubricants, waxes, preparations for fire extinguishers, and prepared solvents. 
The U.S. participates in four ISO technical committees with work related to this group. These are in the areas of pesticides (TC 81), surface active agents (TC 91), petroleum products and lubricants (TC 28). The U.S. is particularly active in TC 28 where it holds the TC secretariat and chairmansin along with eleven out of thirty SC and WG secretariats.

As mentioned previously in the organic chemicals and Inorganic Chemicals discussion, the U.S. is registered as a non-voting observer member of ISO/TC 47 on Chemistry.

Commodity Code 65 - Textile, Yarn, Fabric, and Related Articles- This category consists of natural and man-made yarns, threads, and fabrics as well as articles such as towels, bedding, and floor coverings. Clothing is not included here, but in Commodity Code 84 on Wearing Apparel and Clothing Accessories.

International standardization activities for this product category are carried out by ISO Technical committee 33Textiles. The U.S. holds 6 of the 56 subcommittee and working group secretariats in this large technical committee. The United Kingdom is the TC secretariat and the last plenary meeting was in 1985 .

Commodity Code 64 - Paper, Paperboard and Manufactures Thereof -The cognizant ISO Technical Committee for this product group is TC 6 - Paper, board and pulps. The U.S. holds four of the 23 (14\%) subcommittee or working group secretariats. The last plenary meeting was in 19.86 and Canada holds the secretariat for the overall technical committee.

Commodity Code 88 - Photographic Equipment and Supplies and optical Goods - In addition to the obvious cameras, projectors, photographic films, lenses and other associated photographic and optical supplies, this product group also includes watches and clocks, their movements and parts thereof.

The U.S. holds the TC secretariats for the two predominant ISO committees involved in international standards for the product group. These are ISO/TC 36 - Cinematography and ISO/TC 42 Photography. It participates in related ISO and IEC committees involved with optics (ISO/TC 172), recording (IEC/TC 60) and audio/video engineering (IEC/TC 84). In the area of time keeping and time measurement, the U.S. is registered as a non-voting observer member of ISO/TC 114 - Horology.

Commodity Code 66 - Nonmetallic Mineral Manufactures - - This category contains a wide variety of products, including cement, stone building materials, insulation, asbestos products, glass, glassware, pottery, and diamonds and other precious and semiprecious stones. 
U.S. participation levels and leadership roles in the 14 separate ISo technical committees with interests in this product group are not strong with two notable exceptions.

(1) The U.S. holds the secretariat and chairmanship of TC 189 on Ceramic Tile. This TC was recently established in 1985; and,

(2) The U.S. holds 6 of the 28 (or 21\%) of the subcommittee and working group secretariats in TC 163 on Thermal Insulation.

The U.S. is registered as a non-voting observer member of the following 5 ISO Technical Committees:

(1) TC 56 - Mica (last meeting was in 1965)

(2) TC 74 - Cement and Lime (last meeting was in 1965)

(3) TC 77 - Products in Fiber Reinforced Cement (last meeting in 1983) - This TC covers asbestos cement products.

(4) TC 152 - Gypsum, Gypsum Plasters and Gypsum Products (1ast meeting was in 1972)

(5) TC 175 - Fluorspar (1ast meeting was in 1986)

The U.S. is listed as "not represented" (i.e., not a participant nor an observer) in ISO Technical Committee 63 - Giass Containers. This committee last met in 1984 and is primarily concerned with the standardization of glass containers used as a means of packaging.

The U.S. holds one subcommittee or working group secretariat in the following three technical committees:

(1) TC 48 - Laboratory Glassware

(2) TC 160 - Glass in Building

(3) TC 166 - Ceramic Ware, Glassware, and Glass Ceramic ware in Contact with Food

The U.S. is registered as a participant in the following three technical committees:

(1) TC 33 - Refractories (last meeting in 1985)

(2) TC 71 - Concrete, Reinforced Concrete and Pre-stressed Concrete (last meeting in 1985) 
Commodity Code 56 - Fertilizers and Fertilizer Materials - - The U.S. is a participant member of ISO/TC 134-Fertilizers and Soil Conditioners, but does not hold any of the ten SC or wG secretariats. France holds the TC secretariat and the last meeting was in 1984. The U.S. is a non-voting observer member of ISO/TC 190 - Soil Quality.

Commodity Code 68 - Nonferrous Metals - - Aluminum, nickel, copper and silver are the primary nonferrous metals in this category.

The U.S. participates in 4 of the 5 ISO Technical Committees with interests in the area of nonferrous metals. The U.S. is a nonvoting observer member of ISO TC 18 on Zinc and Zinc Alloys. The last plenary meeting of TC 18 was in 1978. For the other 4 TCS (copper, nickel, light metals and alloys) the U.S. holds 8 of the 65 (12\%) of the subcommittee and working group secretariats. Major TC secretariats for these committees are held by Belgium, Germany, France, Canada, and Australia.

Commodity Code 73 - Metalworking Machinery -. This category consists of metalworking, metalcutting, and metalforming machine tools, as well as metal foundry machinery, rolling mill machinery, welding/soldering equipment and parts.

The U.S. is registered as a participant in 6 of the 7 ISO and IEC Technical Committees relating to this product group -- it only holds non-voting "observer" status in ISO TC 14 on "Shafts for Machinery and Accessories." France and Germany hold the major secretariats for the primary TCs in this group - Machine Tools (ISO TC 39), Welding (ISO TC 44), Limits and Fits (ISO TC 3), and Electric Welding (IEC TC 26). ISO Technical Committee 184 on "Industrial Automation Systems" is a high technology sector committee and was only established in 1983. The U.S. holds 5 of the 18 (or 28\%) secretariats in TC 184. France holds the main TC secretariat.

Commodity Code 67 - Iron and Steel -- The U.S. currently holds 6 of the 35 (17\%) secretariats in ISO Technical Committee 17 on "Steel" covering standardization of cast, wrought, and coldformed steel. In 1978 the U.S. held only 2 of the 35 (or $6 \%$ ) secretariats in TC 17. Japan currently holds the main TC secretariat. The U.S. is registered as a non-voting observer member of Technical Committee 25 on Cast Iron and Pig Iron.

Commodity Code 84 - Wearing Apparel and Accessories -- The ISO activity most related to this product group is TC 133 entitled, "Sizing Systems and Designations for Clothes." The U.S. is registered as a voting participant in this committee. South Africa holds the secretariat and the last plenary meeting was in 1979. 
Commodity Code 55 - Essential oils and Perfume Materials - - This category includes toilet, polishing and cleansing preparations as well as flavor oil mixtures and blends, cosmetics, and soaps.

In ISO, the relevant technical committees are TC 54 - Essential 0i1s and TC 91 - Surface Active Agents. The U.S. is registered as a non-voting observer member of TC 54, whose last meeting was held in 1986 and a participant in TC 91 which also met 1 ast in 1986. As previously identified under other product groups, the U.S. is registered as observer on TC 47 - Chemistry which also relates to this product group.

Commodity Code 63 - Cork and Wood Manufactures, Excluding Furniture - This export group includes cork and wood-based sheets and strips, wood manufactured products, builders woodwork, prefabricated building products, panels, plywood, veneers and cooperage products.

For U.S. interests, participation in the ISo technical committees for standardization work relevant to this product group is in need of improved performance. The U.S. participates in only 1 of the 8 Iso technical committees with technical work affecting this product group. This is ISO/TC 89 - Wood-based Panels. The U.S. is registered as a non-voting observer member in the following 6 Iso technical committees:

(1) TC 55 - Sawn Timber and Sawlogs (1ast meeting in 1982)

(2) TC 59 - Building Construction (last meeting in 1986)

(3) TC 87 - Cork (last meeting in 1985)

(4) TC 99 - Semi-manufactures of Timber (last meeting in 1982)

(5) TC 162 - Doors and windows (last meeting in 1982)

(6) TC 165 - Timber Structures. (last meeting in 1986)

Commodity code 82 - Furniture - Iso standards work for furniture is the responsibility of ISO/TC 136 - Furniture. The U.S. is a non-voting observer member of TC 136. Sweden holds the TC secretariat, chairmanship and three of the 20 SC and WG secretariats.

Commodity Code 61 - Leather, Leather Manufactures and Dressed Furskins - ISO/TC 120 - Leather covers standardization of terminotogy, test methods and sampling for this product group. The U.S. is registered as a non-voting observer member of TC 120. India holds the TC secretariat; the last meeting was in 1984. 
Commodity Code 53 - Dyeing, Tanning, and Coloring Materials -Paints, varnishes, lacquers, stains, pigments, dyeing extracts, and tanning materials of natural or synthetic origin make up this product group.

ISO/TC 35 - Paints and Varnishes conducts international standardization work relative to this product category. It has 28 subcommittees and working groups on various aspects of paints, varnishes and related products, including raw materials. The U.S. is registered as a non-voting observer member of ISO/TC 35. the last plenary meeting was in 1985 and the Netherlands holds the TC secretariat.

Commodity Code 62 - Tires and Tubes for Tires -- In ISO/TC 31 Tires, Rims and Valves - the U.S. maintains a strong position. The U.S. holds the TC secretariat and chairmanship and eleven of the 29 SC and WG secretariats.

Commodity Code 81 - Sanitary, Plumbing, Heating, and Lighting Fixtures -- This category covers furnaces, cooking apparatus, plumbing and lighting fixtures, fittings and parts.

The U.S. participates in four of the six ISO and IEC standards committees involved in setting standards that impact this category of trade merchandise. The two ISO committees in which the U.S. is registered as a non-voting observer are:

(1) TC 109 - 0il Burners and Associated Equipment

(2) TC 116 - Space Heating Appliances

Commodity Code 85 - Footwear -- ISO Technical Committee 137, "Sizing System, Designations and Marking for Boots and Shoes," covers this product category with regard to standardization of sizing ranges, foot measurements, last equipment and terminology. The U.S. is a non-voting "observer" member of this ISO committee. The committee meets infrequently - the last plenary meeting was in 1980. South Africa holds the TC secretariat.

11. Findings and Conclusions

Findings

1. U.S. participation levels (as evaluated in terms of secretariat strength) in both ISO and IEC grew over the 20 year period 1966-1986 in terms of percentage gain in U.S.-held secretariats and improved rankings among member countries. Performance in IEC has been greater than in IsO. Data from Figures 5 and 6 for 1966 and 1986 indicate the following: 


\begin{tabular}{|c|c|c|c|}
\hline secretariats & Ranked & $\begin{array}{r}\frac{\% \text { U.S. -held }}{\text { secretariats }} \\
\end{array}$ & Ranked \\
\hline 9.0 & $\begin{array}{l}3 r d-b e h i n d \\
\text { UK and France }\end{array}$ & 12.6 & $\begin{array}{l}4 \text { th-behind } \\
\text { UK, France } \\
\text { Germany }\end{array}$ \\
\hline 9.4 & $\begin{array}{l}5 \text { th-behind UK, } \\
\text { Nether lands, } \\
\text { France and Ger }\end{array}$ & 16.2 & $\begin{array}{l}2 \text { nd-behind } \\
\text { France }\end{array}$ \\
\hline
\end{tabular}

After a decline of U.S. -held secretariats in IEC from 1976 to 1980 , U.S. secretariats gained $5 \%$ since 1980 . The U.S. has secured 10 TC or SC secretariats in IEC since 1980 including two in the 10 most recently established technical committees or subcommittees. These are IEC/TC 82 - Solar Photovoltaic Energy Systems and IEC/TC 86 - Fiber 0ptics. ISO gains have not been as significant according to the data compiled for this report. U.S.-held secretariats in ISO have increased approximately $2 \%$ since 1983. ISO has established 13 new technical committees since 1980 which created 99 new TC, SC and WG secretariats. The U.S. was named secretariat for 13 of these new standards groups ( 1 TC, 4 SC and 8 WG). The only new U.S.-held secretariat at the TC level is for ISO/TC 189 - Ceramic Tile. Five of the new U.S.held secretariats are in ISO/TC 184 - Industrial Automation System - a field where U.S. leadership has been of international significance. The U.S. is registered as a non-voting observer member in 5 of the 13 new TCS. They are: ISO/TC 179 - Masonry; ISO/TC 182 - GeotechniCS; ISO/TC 181 - Safety of Toys; IS0/TC 186 - Cutlery and Table and Decorative Metal Hollow-ware; ISO/TC 190 - Soil Quality.

2. As discussed in section 5.2, ISo member bodies from each member country are registered by voting or non-voting status in each ISO Technical committee. Voting is limited to "participating" members; non-voting to "observer" members. ISO annually publishes a country-by-country listing indicating membership status in each Iso technical committee. The participant-observer mix (which may also be calculated as the participant: observer ratio -. "p:0") varies from country to country depending on many factors -- among them are extent of industrial development, value placed on influencing standards development (a "Participating" delegation) or value it places on obtaining information (an "Observer" delegation). In 1986, P:0 ratios ranged from 0.1 for Yugoslavia (16 "p" memberships to 139 "0" memberships) to 17.2 for Federal Republic of Germany. The P:0 ratio for the U.S. in 1986 was 2.4 - an improvement over the 1.9 for 1966. Japan showed the greatest increase in $P: 0$ ratio over the 20 year period -- in 1966 Japan was 0.2 , and in 1986 it increased to 1.4 . 
3. The general improvements in U.S. participation levels and secretariat strength in ISO and IEC from 1960 through 1986 cited in the first two findings above appear to correlate inversely with the gradual decline in the overall U.S. share of world exports (see Figures 1, 2, 4 and 6). U.S. involvement in international standards activities seems to correlate more directly with the sustained growth of world trade overall rather than on the level of U.S. exports - including export of manufactured goods which have also deteriorated over the same period. There exists the possibility that U.S. participation gains in international standards activities and the benefits that may accrue therefrom best serves the interests of U.S.-based multi-national corporations whose business enterprises nave become increasingly international and whose profits relate to global markets where production facilities, commodities, goods and services and money cross various national borders.

4. Although the effect of such economic factors as tariffs and quotas on U.S. exports can be quantified, it is difficult to estimate the effect of any direct benefits that accrue from participation in international standardization activities. As previously cited in section 1 of this report there are significant intangible benefits winich accrue to those industries that do participate.15 U.S. companies have indicated that various benefits accrue to them from participation in international standardization activities. Such participation:

- Contributes to the development of a broader market base for exports.

o Provides source of state-of-the-art knowledge on foreign technology.

o Results in the development of higher quality standard benefitting U.S. products.

- Provides the basis for defensive actions to counter foreign competition.

- Promotes universal product or test method standards to enhance economies in manufacturing operations.

- Provides for professional growth and face-to-face contact with authorities from foreign product approval agencies (minimizes possible regulatory surprises).

However, the section of this report comparing 1986 export data with U.S. participation in ISO/IEC (Section 10.3) indicates that

15 Cooke, op. cit., p. 4. 
the U.S. Tevel of effort tends to favor those product groups with newer technologies and higher export values. Those product groups that predominate as export strengths for the U.S. appear to be those with electrical and electronic-related content which are primarily IEC-related subjects. Overall participation levels, U.S.-held secretariat strengths, and interest by U.S. companies favor IEC activities across the board more than they do ISO subject areas. ISO subject areas are more diverse than IEC subjects, and more fully span the interests of the industry sectors with strong and weak U.S. trade performance.

5. U.S. export success and participa.tion in ISO/IEC standardization activities are evident in certain product sectors. The apparent strengths regarding standards participation and dollar volume of U.S. exports are in:

o office machines and ADP equipment

o the aircraft segment of transport equipment

o electrical machinery, apparatus, and appliances

- power generating machinery

o earthmoving machinery, agricultural machinery and specialized equipment for petroleum and natural gas industries

o electro-medical equipment segment of professional, scientific and controlling instruments

- petroleum products and lubricants segment of organic chemicals and related products

o telecommunications equipment

o synthetic resins, rubber and plastic materials

Exports for 1986 are lower for some of the more basic product groups where there also exists an apparent underrepresentation of U.S. interests in ISO-related international standardization activities:

- wood manufactured products - particularly prefabricated building components and materials

footwear

o space heating appliances, oil burners and associated equipment

o paints, varnishes, lacquers, etc.

o leather goods

o furniture

o essential oils

o fertilizer products

o toys

Conclusions

1. Information on U.S. participation levels in ISO and IEC may not be completely accurate and trade data is subject to many economic factors such as changes due to currency exchange rates, 
differential economic growth in foreign countries, and structural shifts in industry sectors. Improved record-keeping and followup by ANSI and better liaison with NBS Office of Associate Director for Industry and Standards would assist NBS in monitoring the adequacy of U.S. participation in international standardization activities.

2. ANSI, U.S. industry, trade associations, standards developers and other interested parties should maintain U.S. gains and comparative advantages held in current ISO/IEC affiliations. Steps can be taken to strengthen the U.S. position in standardization technical committees dealing with products where U.S. can exploit its potentials for exporting.

3. A national educational and motivational program by ANSI and industry trade groups could be developed to make people more aware of the role of international standards and the benefits to the U.S. economy and trade balances that can result from improved U.S. participation. Such a program is crucial at this time of increased emphasis on competitiveness, the prospects of protectionist legislation, and the many changes underway in U.S. industry--downsizing, restructurings, mergers, takeovers, etc.

4. In order to analyze, understand, and better publicize the benefits of U.S. participation in international standards activities, anecdotal experiences of successes (or failures) are essential. These should be communicated to the NBS/ADIS at the following address:

Office of Standards Code and Information

Attn: Mr. Patrick W. Cooke

National Bureau of Standards

Building 101, Room A629

Gaithersburg, MD 20899 
Figure 1

Figure 2

Figure 3

Figure 4

Figure 5

Figure 6

Figure 7

Table 1

Table 2

Table 3

Table 4

Table 5

Table 6

Table 7

Table 8

Table 9

U.S. Share of World Exports and

Page

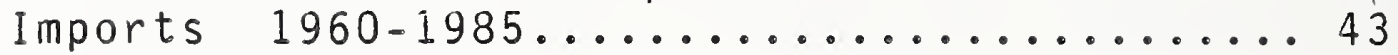

Change in Exports and Imports of Selected

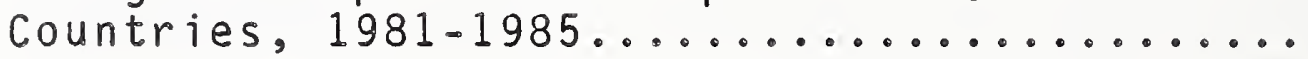

Merchandise Exports and Imports of Leading

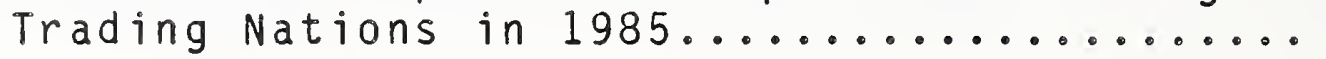

ISO Secretariats Held by Various Countries,

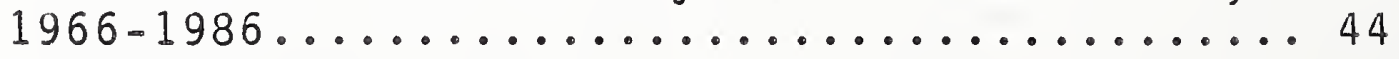

ISo Standards Development Activities, 1966-1986.

IEC Secretariats Held by Various Countries, $1966-1986$

IEC Standards Development Activities, $1966-1986$

Membership of Countries in ISO, IEC, and GATT Standards Code Activities............ 48

U.S. Status in ISO Technical Committees..... 53

Basic Data on Top 10 U.S. Trading Partners with

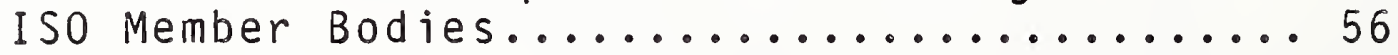

Chronological Distribution of U.S.-Held Secretariats of IEC Technical Committees

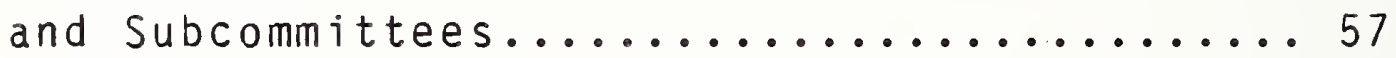

Listing of International Standards Directly Adopted in the United States as "ANSI/ISO"

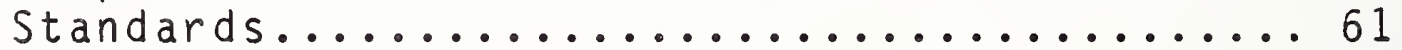

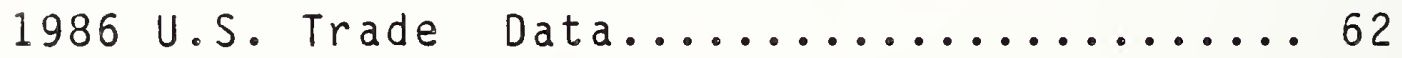

ISO Secretariats/Chairmanships and

Participation Levels Applicable to Major

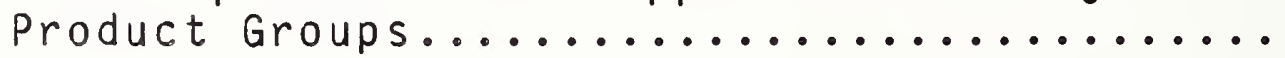

IEC Secretariats/Chairmanships for IEC TCS

and SCS Applicable to Major Product Groups...

Analys is of 1986 U.S. Exports and U.S. Held ISO/IEC Secretariats by Data Sets..........6 65 
Figure 1.

U.S. SHARE OF WORLD EXPORTS \& IMPORTS $1960-85$

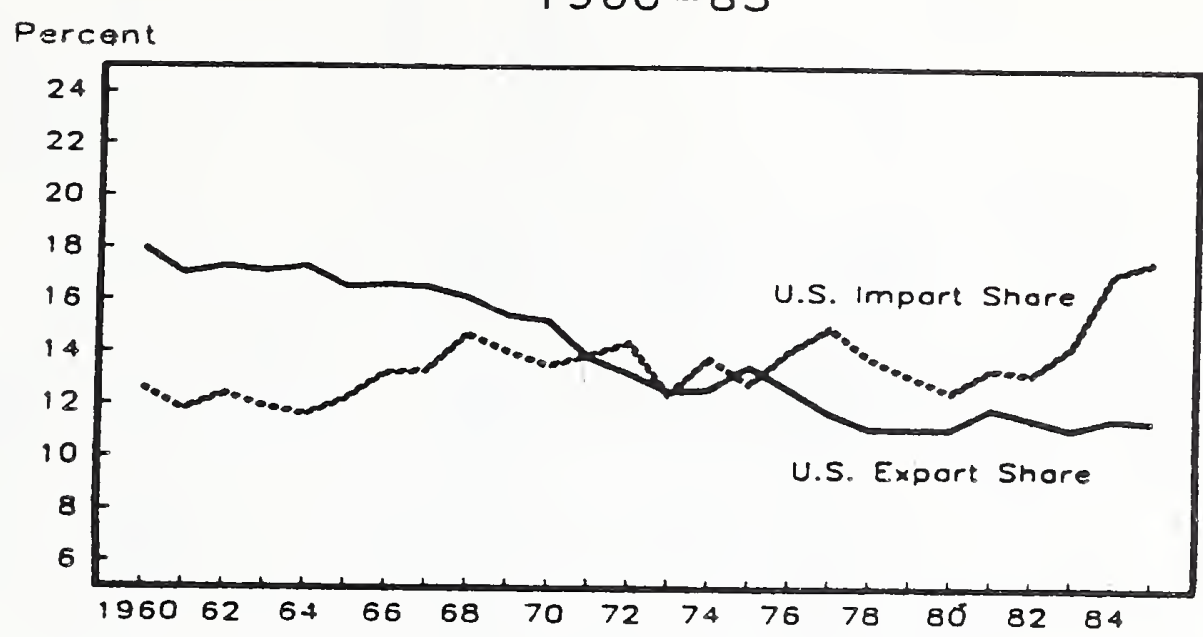

Figure 2

CHANGE IN EXPORTS AND IMPORTS OF SELECTED COUNTRIES, :981-85

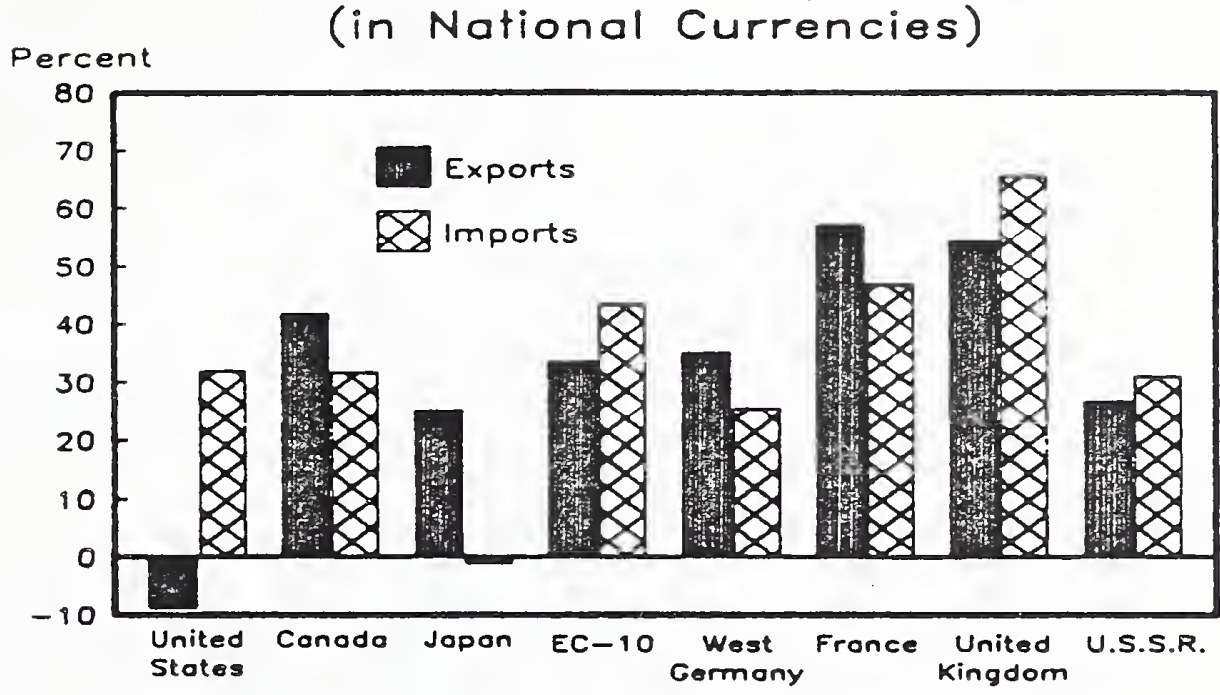

Figure 3.

MERCHANDISE EXPORTS AND IMPORTS OF LEADING TRADING NATIONS IN 1985 Billian Dollars (Exports, f.o.b.; Imports, c.i.f.)

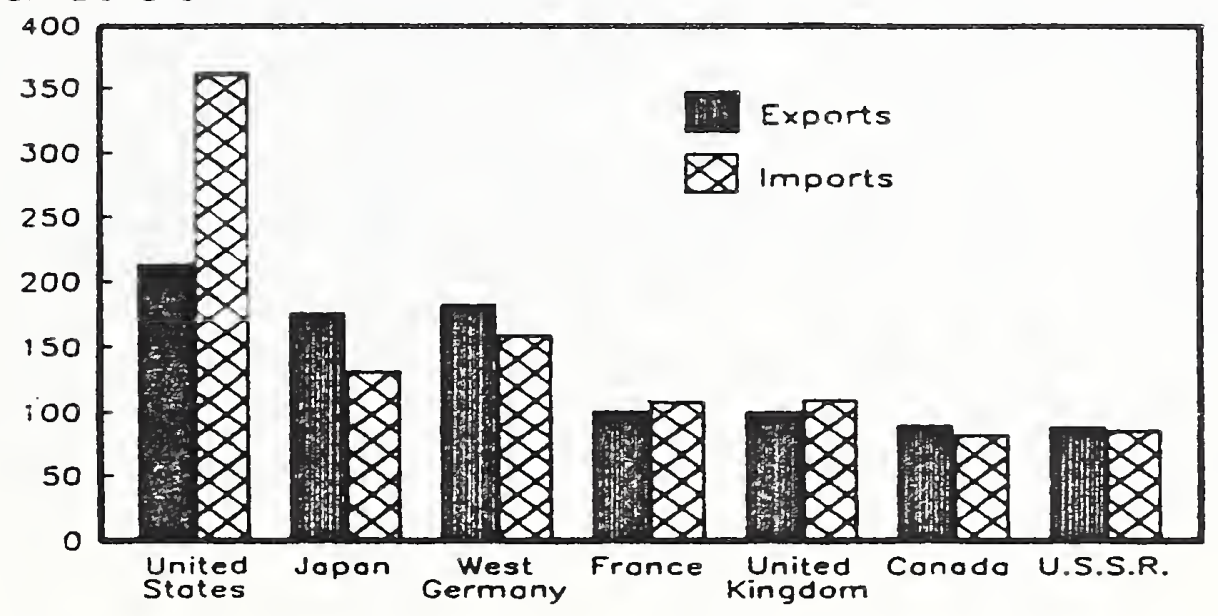

Source; "United States Trade Performance In 1985 and Outlook", U.S. Dept. of Commerce, International Trade Administration, Oct., 1986 . 


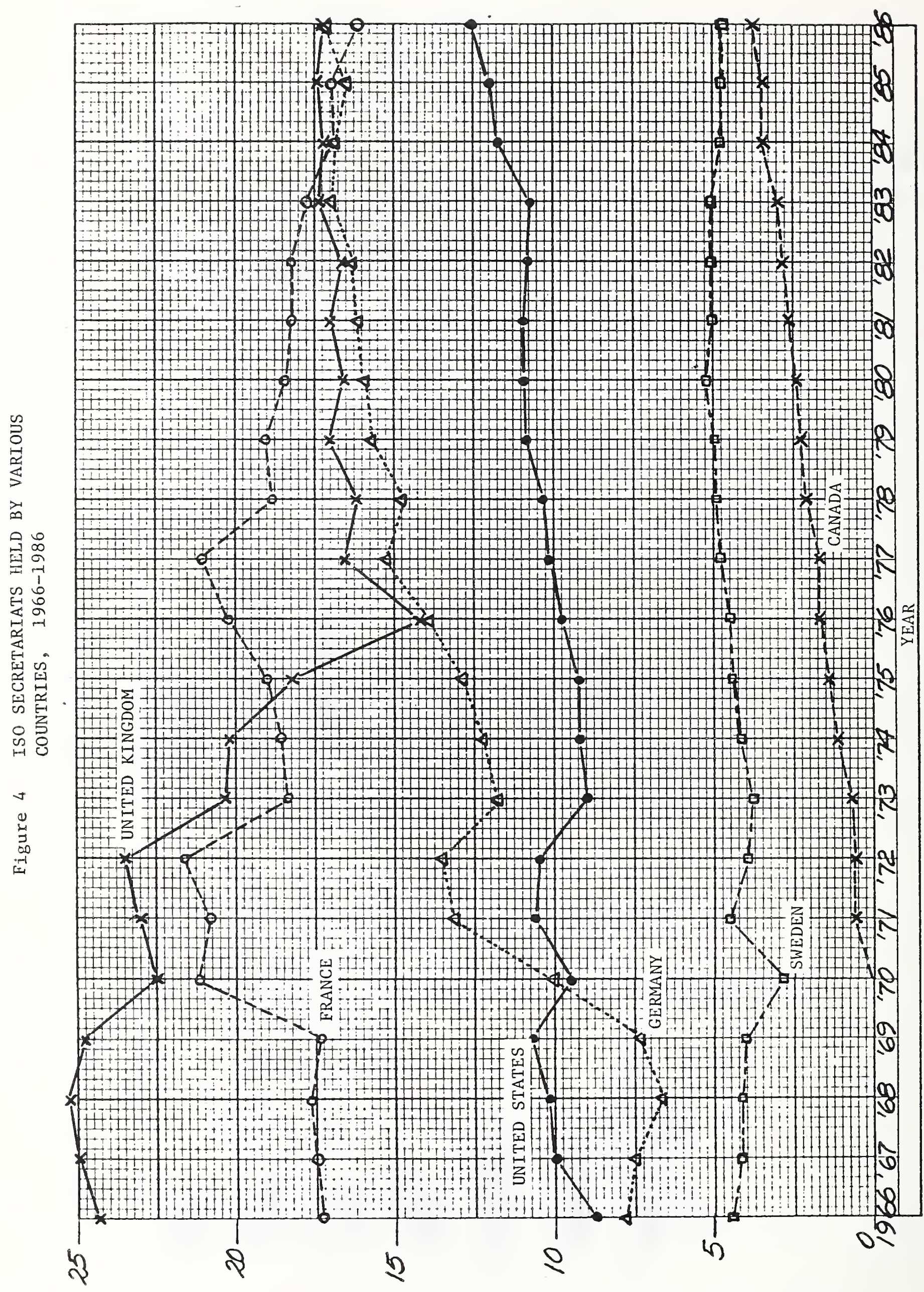

$(\mathrm{S}, \mathrm{OM}$

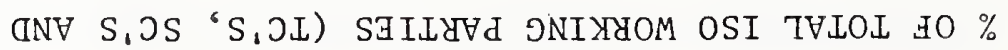




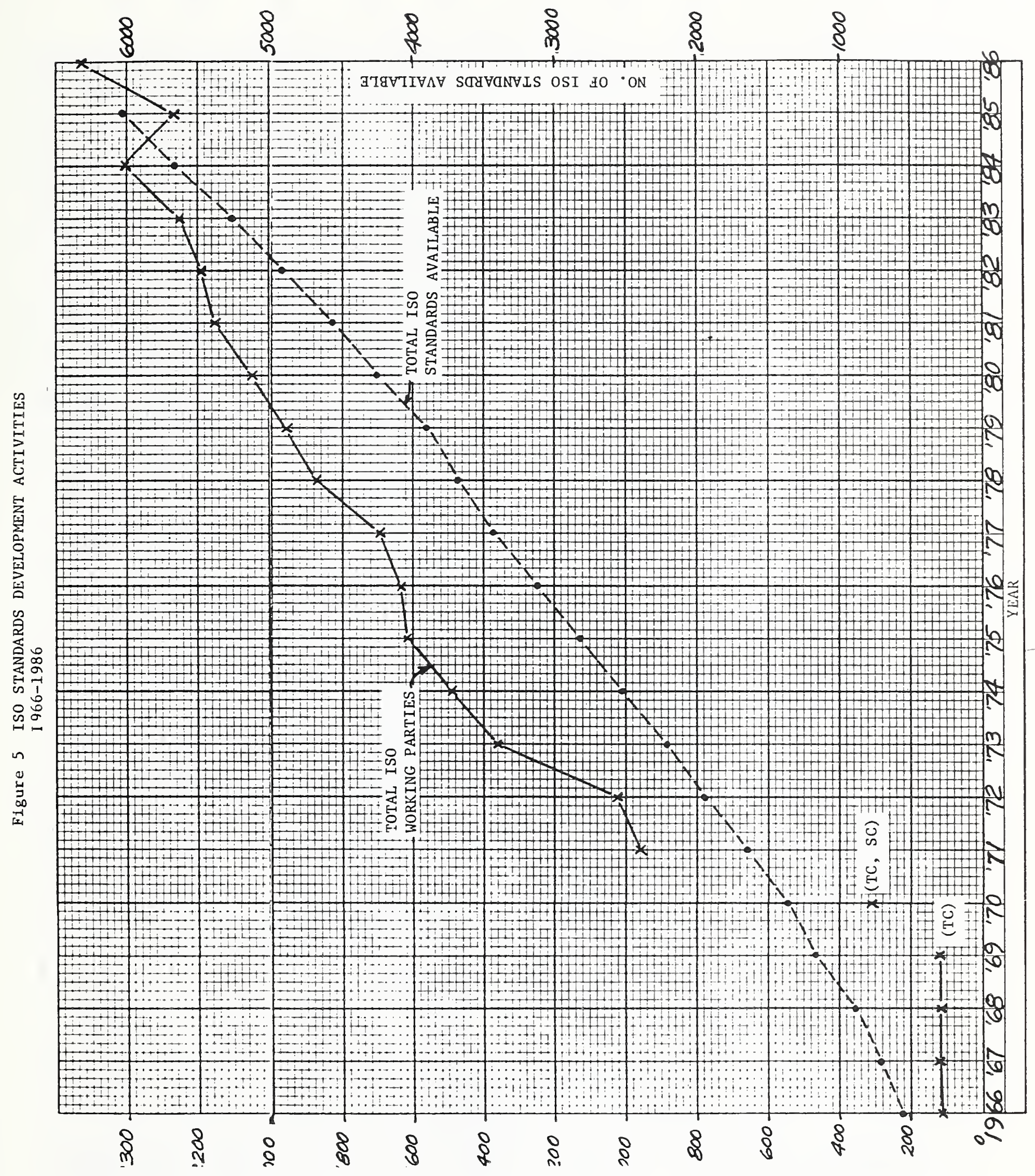




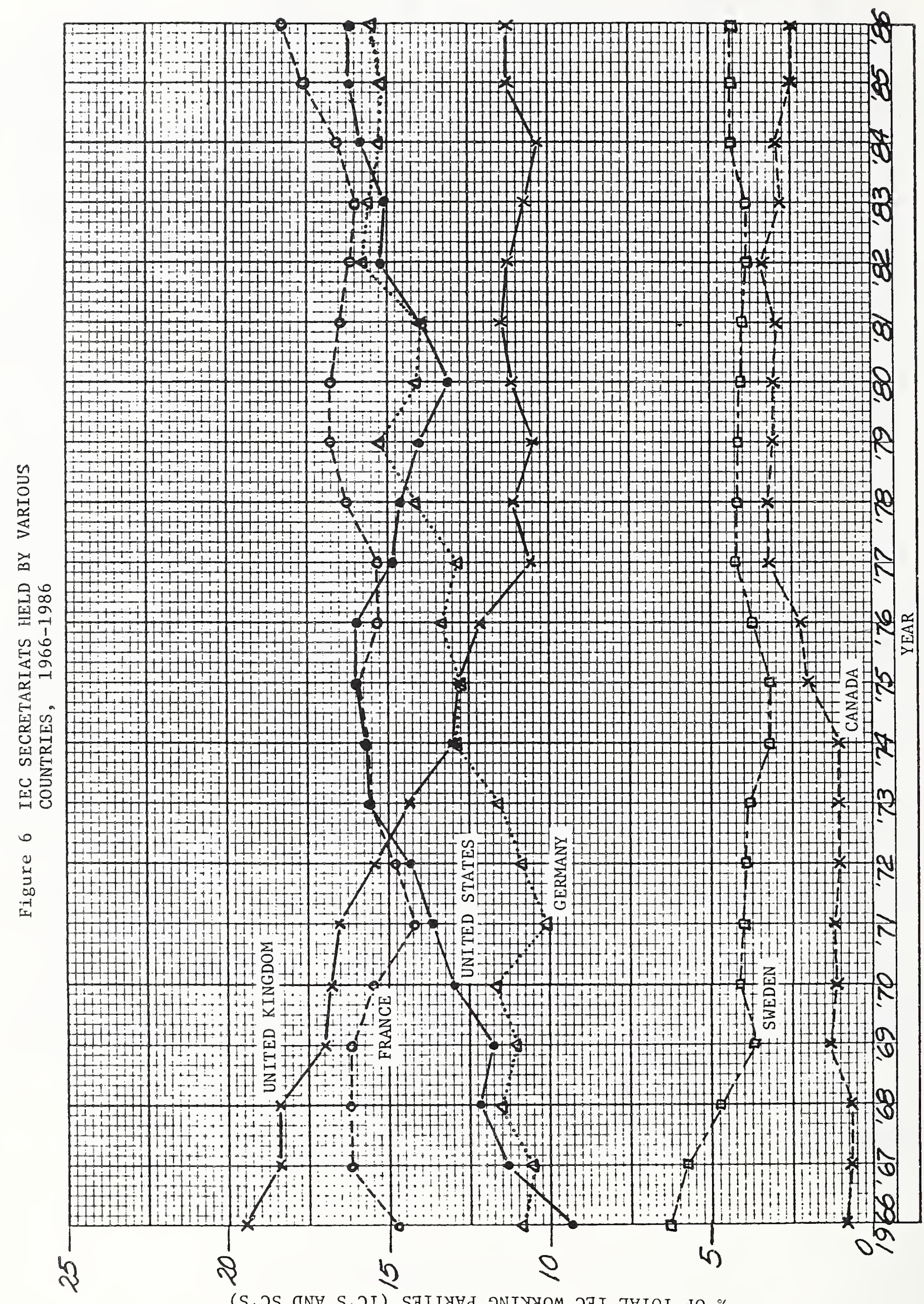

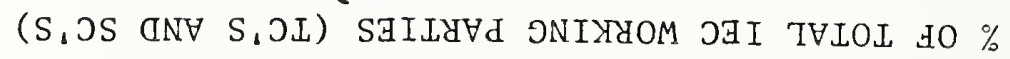


MEMBERSHIP OE COUNTRIES IN ISO, IEC, AND GATT STANDARDS CODE ACTIVITIES

\begin{tabular}{|c|c|c|c|c|}
\hline COUNTRY & I so & IEC & GATT & $\begin{array}{l}\text { STANDARDS } \\
\text { CODE }\end{array}$ \\
\hline \multicolumn{5}{|l|}{ INDUSTRIALIZED COUNTRIES } \\
\hline AUSTRALIA & M & M & & 0 \\
\hline AUSTRIA & $\bar{M}$ & $M$ & & $\mathrm{M}$ \\
\hline CANADA & $\mathrm{M}$ & $M_{\infty}$ & & $\mathrm{M}$ \\
\hline \multicolumn{5}{|l|}{ EUROREAN COMMUNITY } \\
\hline BELGIUM & $\overline{\mathrm{M}}$ & $\bar{M}$ & & $\bar{M}$ \\
\hline DENMARK & $\mathrm{M}$ & $\bar{M}$ & & $\mathrm{M}$ \\
\hline FRANCE & $\bar{M}$ & $\mathrm{M}$ & & $\bar{M}$ \\
\hline WEST GERMANY (FRG) & $\bar{M}$ & $\mathrm{M}$ & & $\mathrm{M}$ \\
\hline GREECE & $\overline{\mathrm{M}}$ & & & M 2I \\
\hline IRELAND & $\bar{M}$ & $\bar{M}$ & & $\mathrm{M}$ \\
\hline ITALY & $\mathrm{M}$ & $\mathrm{M}$ & & M \\
\hline \multirow{2}{*}{\multicolumn{5}{|c|}{ LUXEMEMBURG }} \\
\hline & & & & $M$ \\
\hline PORTUGAL & $\bar{M}$ & $\mathrm{M}$ & & $\bar{M}$ \\
\hline SPAIN & $\bar{M}$ & $\mathrm{M}$ & & $M$ \\
\hline \multicolumn{5}{|l|}{ UNITED KINGDOM } \\
\hline \multicolumn{5}{|l|}{$\begin{array}{l}\text { EINLAND } \\
\text { JAPAN }\end{array}$} \\
\hline JAPAN & $\bar{M}$ & M & & $\mathrm{M}$ \\
\hline NEW ZEALAND & $\mathrm{M}$ & $\mathrm{M}$ & & $\bar{M}$ \\
\hline \multicolumn{5}{|l|}{ NORWAY } \\
\hline \multicolumn{5}{|l|}{ SOUTH AFRICA } \\
\hline \multicolumn{5}{|l|}{ SWEDEN } \\
\hline \multicolumn{5}{|l|}{ SWITZERLAND } \\
\hline \multicolumn{5}{|l|}{ UNITED STATES } \\
\hline \multicolumn{5}{|l|}{ ICELAND } \\
\hline \multicolumn{5}{|l|}{ TURKEY } \\
\hline NEWLY INDUSTRIALIZING COUNTRIES & $\underline{N I C \cdot S)}$ & & & \\
\hline ARGENT INA & M & M & & $\mathrm{M} I /$ \\
\hline BRAZIL & $\overline{\mathrm{M}}$ & $\bar{M}$ & & $\mathrm{M}=$ \\
\hline CHILE & $\bar{M}$ & & & $\overline{\mathrm{M}}$ \\
\hline COLOMBIA & $\bar{M}$ & & & $\overline{0}$ \\
\hline HONG KONG & $\mathrm{C}$ & & & $\bar{M}$ \\
\hline INDIA & $M$ & $\mathrm{M}$ & & $\bar{M}$ \\
\hline ISRAEL & $\mathrm{M}$ & $\mathrm{M}$ & & 0 \\
\hline $\begin{array}{l}\text { SOUTH } \\
\text { KOREA }\end{array}$ & $\mathrm{M}$ & $\mathrm{M}$ & & $M$ \\
\hline SINGAPORE & $\mathrm{M}$ & & & $\bar{M}$ \\
\hline TAIWAN & $\bar{M}$ & & & \\
\hline MEXICO & $\mathrm{M}$ & $\mathrm{M}$ & & $\mathrm{M}$ \\
\hline & & & - & \\
\hline & & & & \\
\hline & & & & \\
\hline
\end{tabular}


AEGHAN I ST AN

ALGER I A

ANGOLA

ANGU I LLA

ANT IGUA

ARUBA

BAFAMAS

BAHRAIN

BANGL ADESH

BARBADOS

BELIZE

BENIN

BERMUDA

BHUTAN

BOLIVIA

BOTSWANA

BR IND OCEAN TERRITORY

BRITISH VIRGIN ISLANDS

BRUNEI

BURKINA (UPFER VOLTA)

BURMA

BURUNDI

CAMBODIA (KAMPUCHEA)

CAMEROON

CAPE VERDE

CAYMAN ISLANDS

CENTRAL AERICAN REPUBLIC

CHAD

CHR ISTMAS ISLAND

CUCOS (KEELING) ISLANDS

COMOROS

CONGO

COOK ISLANDS

COSTA RICA

CYPRUS

DJ IBOUT I

DOMINICA

DOMINICAN REPUBLIC

ECUADOR

EGYPT

EL SALVADOR

EQUATORI AL GUINEA

ETHIOPIA

FALKLAND ISLANDS

EIJI

ERENCH GUI ANA

FRENCH IND OCEAN AREAS

FRENCH PACIEIC ISLANDS

FRENCH POLYNESIA 


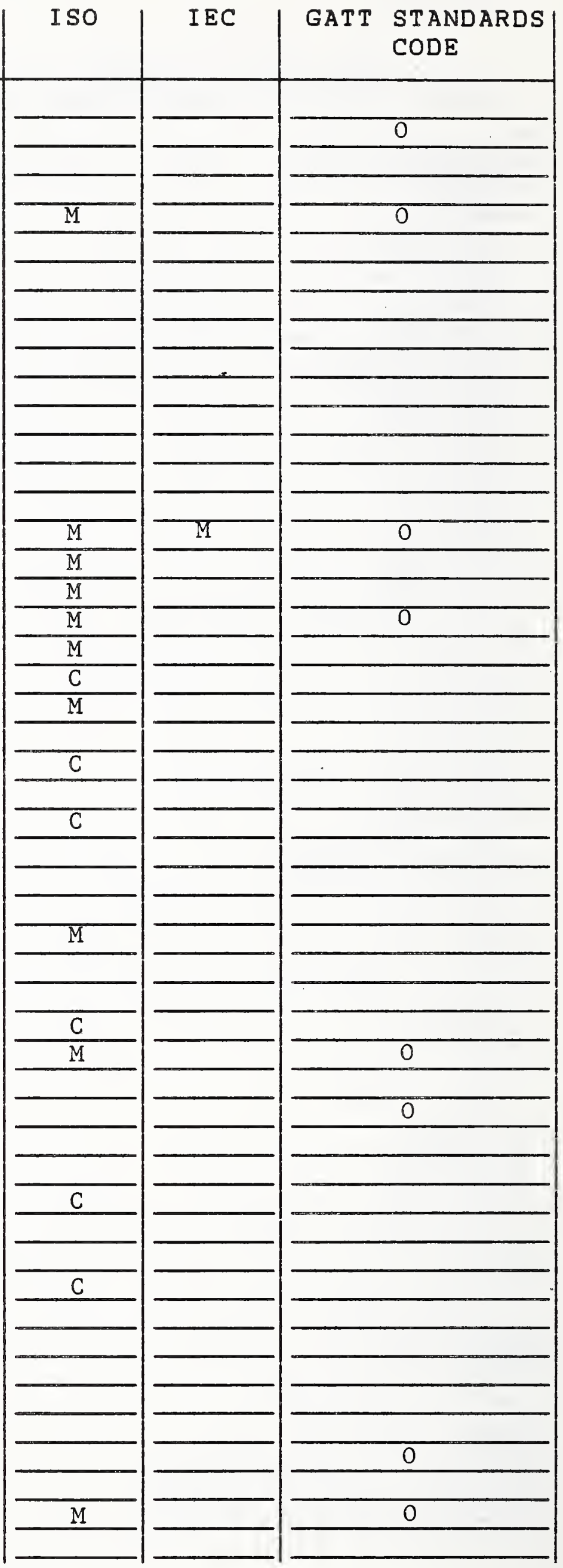


TABLE 1, CONT'D.

\begin{tabular}{|c|}
\hline NOREOLK ISLAND \\
\hline OMAN \\
\hline PACIEIC TRUST TERR. \\
\hline PAKISTAN \\
\hline PANAMA \\
\hline PAPUA NEW GUINEA \\
\hline PARAGUAY \\
\hline PEPU \\
\hline PHILIPPINES \\
\hline PITCAIRN ISLAND \\
\hline QATAR \\
\hline RWANDA \\
\hline SAO TOME AND PRINCIPE \\
\hline SAUDI ARABIA \\
\hline SENEGAL \\
\hline SEYCHELLES \\
\hline SIERRA LEONE \\
\hline SOLOMON ISLANDS \\
\hline SOMALIA \\
\hline SRI LANKA (CEYLON) \\
\hline ST CHRISTOPHER-NEVIS \\
\hline ST HELENA \\
\hline ST LUCIA \\
\hline \multirow{2}{*}{$\begin{array}{lll}\text { ST } & \text { PIERRE } \\
\text { ST } & \text { VINCENT } & \text { AND G GRENADINES } \\
\end{array}$} \\
\hline \\
\hline SUDAN \\
\hline SUR INAME \\
\hline SWAZ ILAND \\
\hline SYRIA \\
\hline TANZANIA \\
\hline THAILAND \\
\hline TOGO \\
\hline TOKELAU ISLANDS \\
\hline TONGA \\
\hline TRINIDAD AND TOBAGO \\
\hline TUNISIA \\
\hline TURKS AND CAICOS ISLANDS \\
\hline TUVALU \\
\hline UGANDA \\
\hline UNITED ARAB EMIRATES \\
\hline URUGUAY \\
\hline VANUATU (NEW HEBRIDES) \\
\hline VENEZUELA \\
\hline WALLIS AND EUTUNA \\
\hline WESTERN SAMOA \\
\hline YEMEN (ADEN) (S YEMEN) \\
\hline ZAIRE \\
\hline ZAMBIA \\
\hline ZIMBABWE (RHODESIA) \\
\hline
\end{tabular}

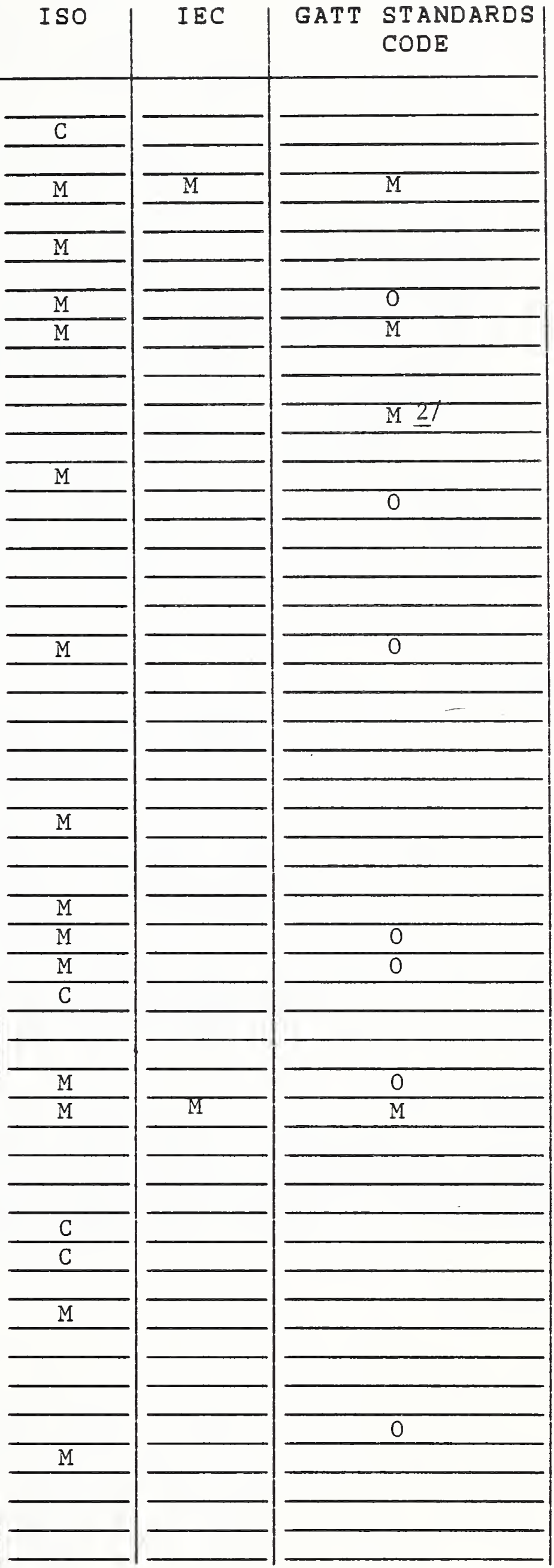


TABLE 1, CONT'D.

\begin{tabular}{|c|c|c|c|c|}
\hline COUNTRY & I SO & IEC & GATT & $\begin{array}{l}\text { ST ANDARDS } \\
\text { CODE }\end{array}$ \\
\hline \multicolumn{5}{|l|}{ NON-MARKET ECONOMIES (NME'S) } \\
\hline ALBANIA & $\mathrm{M}$ & & & \\
\hline BULGAR I A & $\mathrm{M}$ & $\mathrm{M}$ & & 0 \\
\hline CHINA & $\mathrm{M}$ & $\mathrm{M}$ & & \\
\hline CUBA & $\mathrm{M}$ & & & 0 \\
\hline CZECHOSLOVAKIA & $\mathrm{M}$ & $\mathrm{M}$ & & $\mathrm{M}$ \\
\hline \multicolumn{5}{|l|}{ ESTONIA } \\
\hline EAST GERMANY (GDR) & & $\mathrm{M}$ & & \\
\hline HUNGARY & $\bar{M}$ & $\mathrm{M}$ & & $\mathrm{M}$ \\
\hline \multicolumn{5}{|l|}{ LATVIA } \\
\hline \multicolumn{5}{|l|}{ LITHVANIA } \\
\hline MONGOLIA & $\mathrm{M}$ & & & \\
\hline NORTH KOREA & $\mathrm{M}$ & $\mathrm{M}$ & & \\
\hline POLAND & $\mathrm{M}$ & $\mathrm{M}$ & & 0 \\
\hline ROMANIA & $\bar{M}$ & $\bar{M}$ & & $\bar{M}$ \\
\hline USSR & $\mathrm{M}$ & $\mathrm{M}$ & & \\
\hline VIETNAM & $\mathrm{M}$ & & & \\
\hline YUGOSLAVIA & $\bar{M}$ & $\bar{M}$ & & $\bar{M}$ \\
\hline
\end{tabular}

LEGEND:

"M" indicates that country is represented as a Member Body in ISO, a National Committee in IEC, or a signatory to the GATT Agreement on Technical Barriers to Trade (the "Standards Code") as of June 1986.

"C" indicates that country is a Correspondent Member in ISO (generally indicates that the country does not yet have its own national standards body).

"O" indicates that country has "observer" status in GATT Standards Code Committee. ISO and IEC are among seven international organizations that attend meetings in an "observer" capacity.

FOOTNOTES:

II The European Community is a signatory to all the GATT agreements. Individual European Community member states are signatories to the Standards Code and Civil Aircraft Code as these Codes go beyond European Community authority.

2/ Signed subject to ratification.

\section{SOURCES:}

1. "ISO Participation," ISO, Feb., 1987; "ISO Memento 1987," ISO, 1987 .

2. "IEC Yearbook, 1987 , IEC, June 1987.

3. "Composition of the Committee on Technical Barriers to Trade," GATT Document, Sept. 25, 1986.

4. Major country groups derived from information provided by:

o U.S. Dept. of Commerce, International Trade Administration, office of Trade and Investment Analysis.

- U.S. International Trade Commission, Tariff Schedule of the United States, annotated (TSUSA), 1986. 


\section{TABLE 2}

U.S STATUS IN ISO TECHNICAL COMMITTEES (TC)

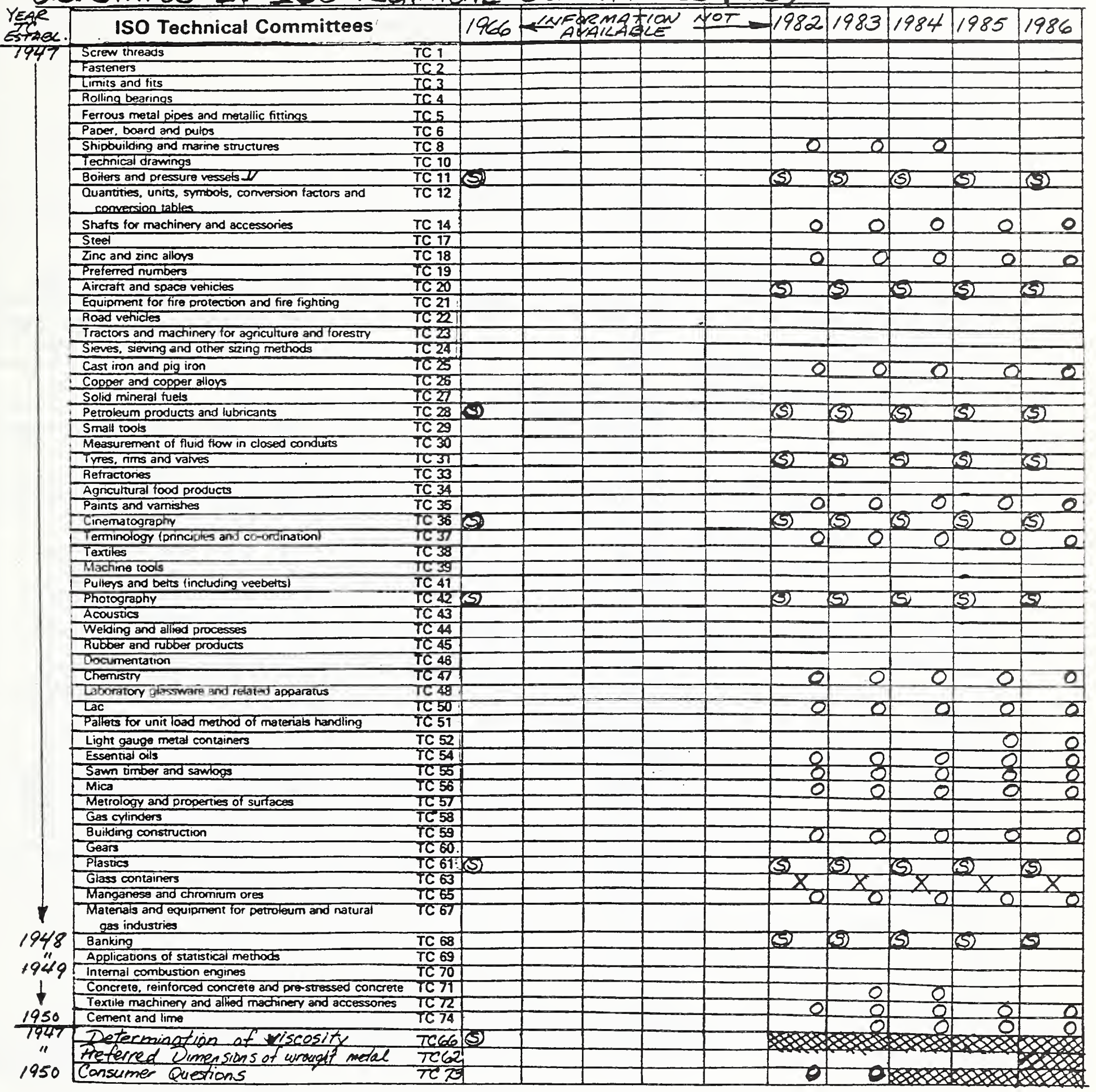


TABLE 2 , CONT'D. - U.S. Status In ISO TECHNICAL CoMmitTEES

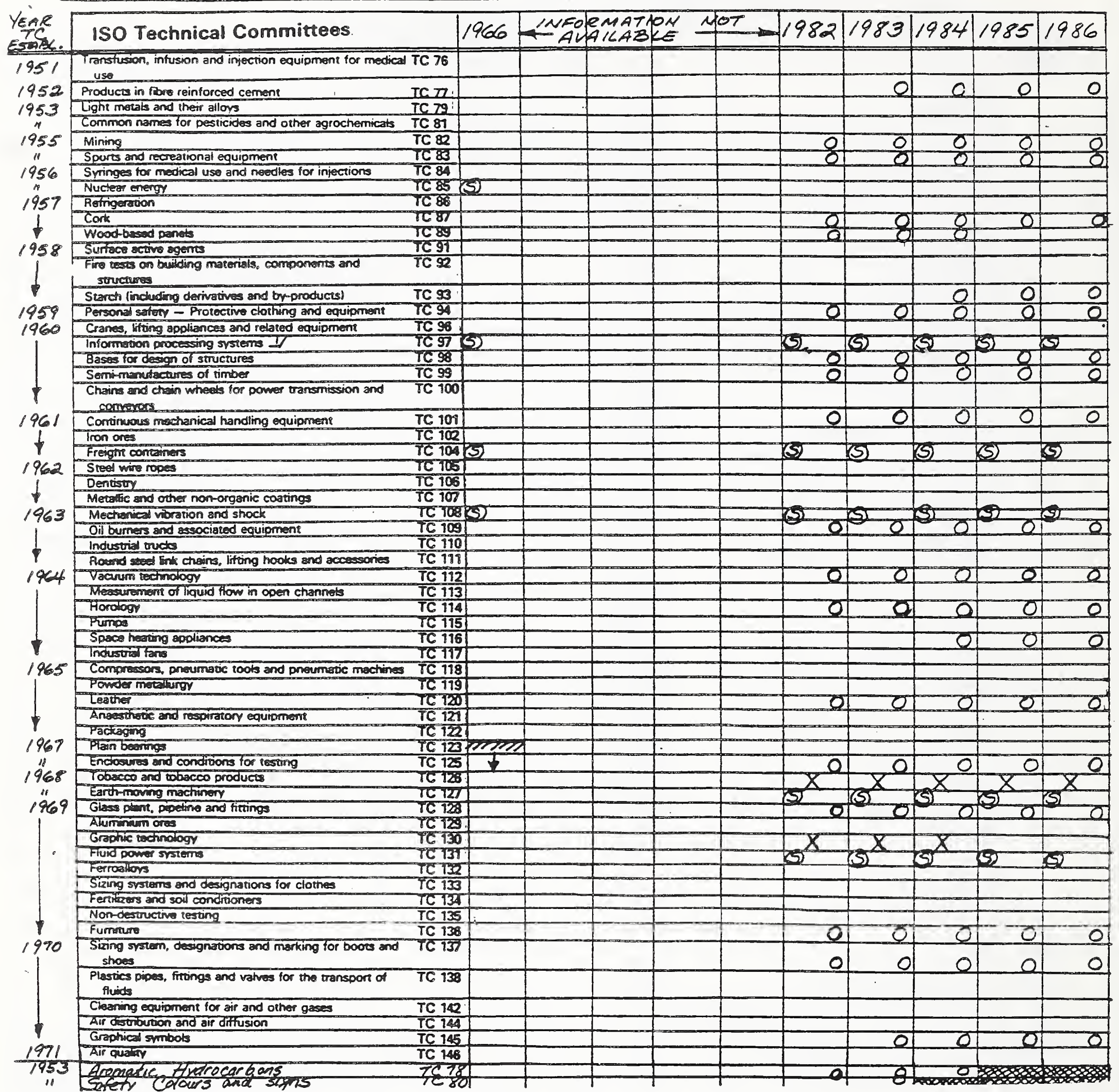




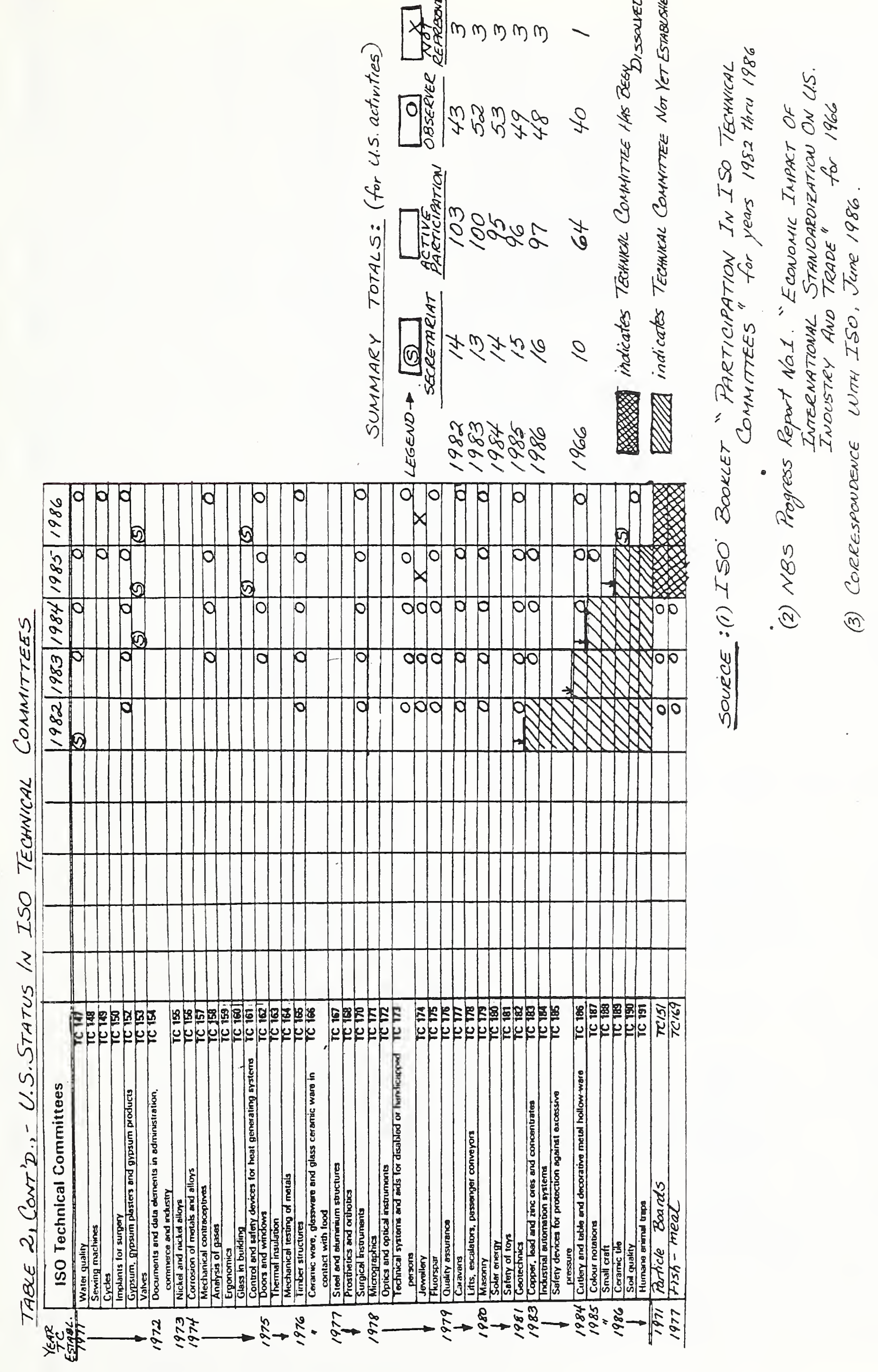




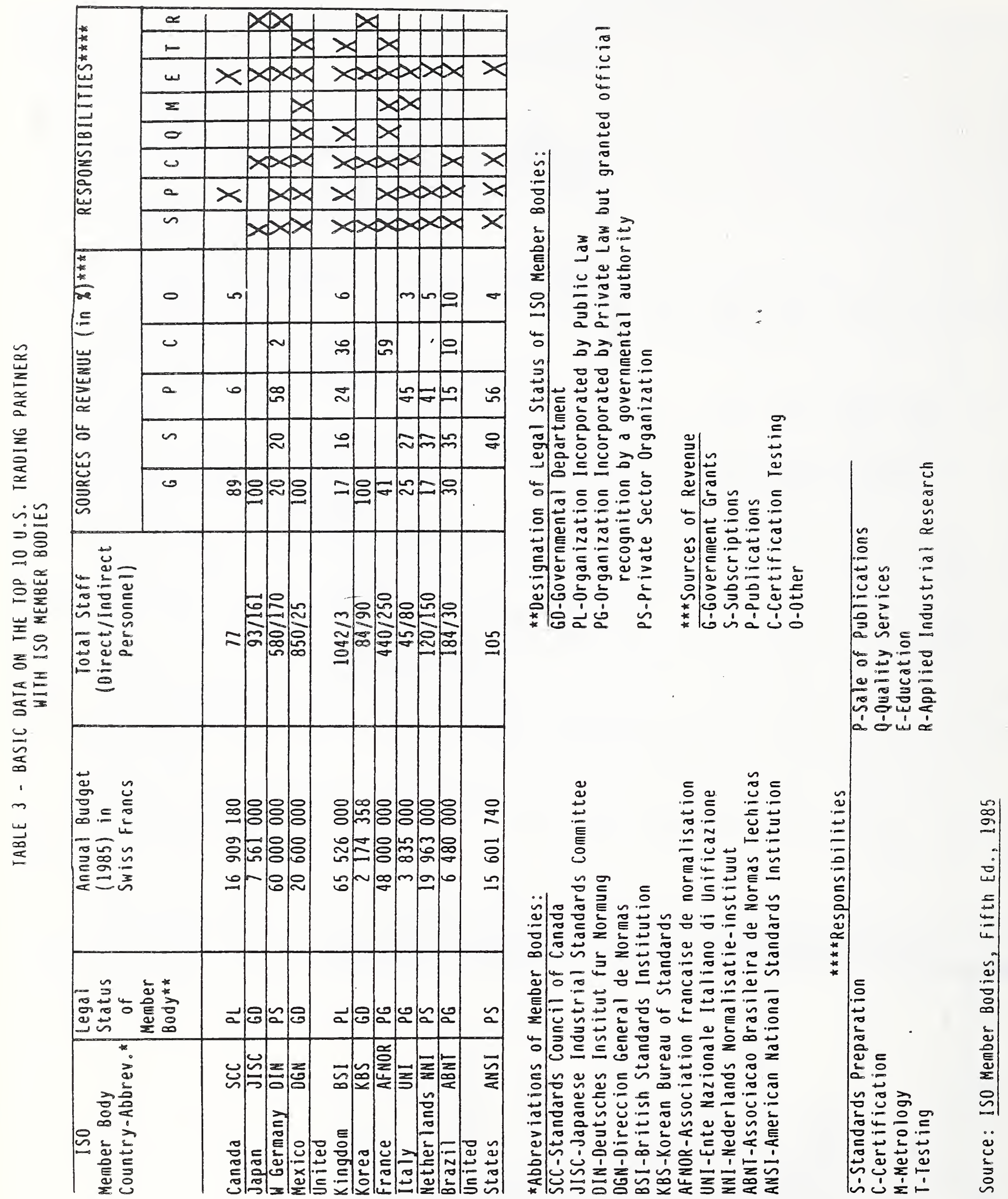




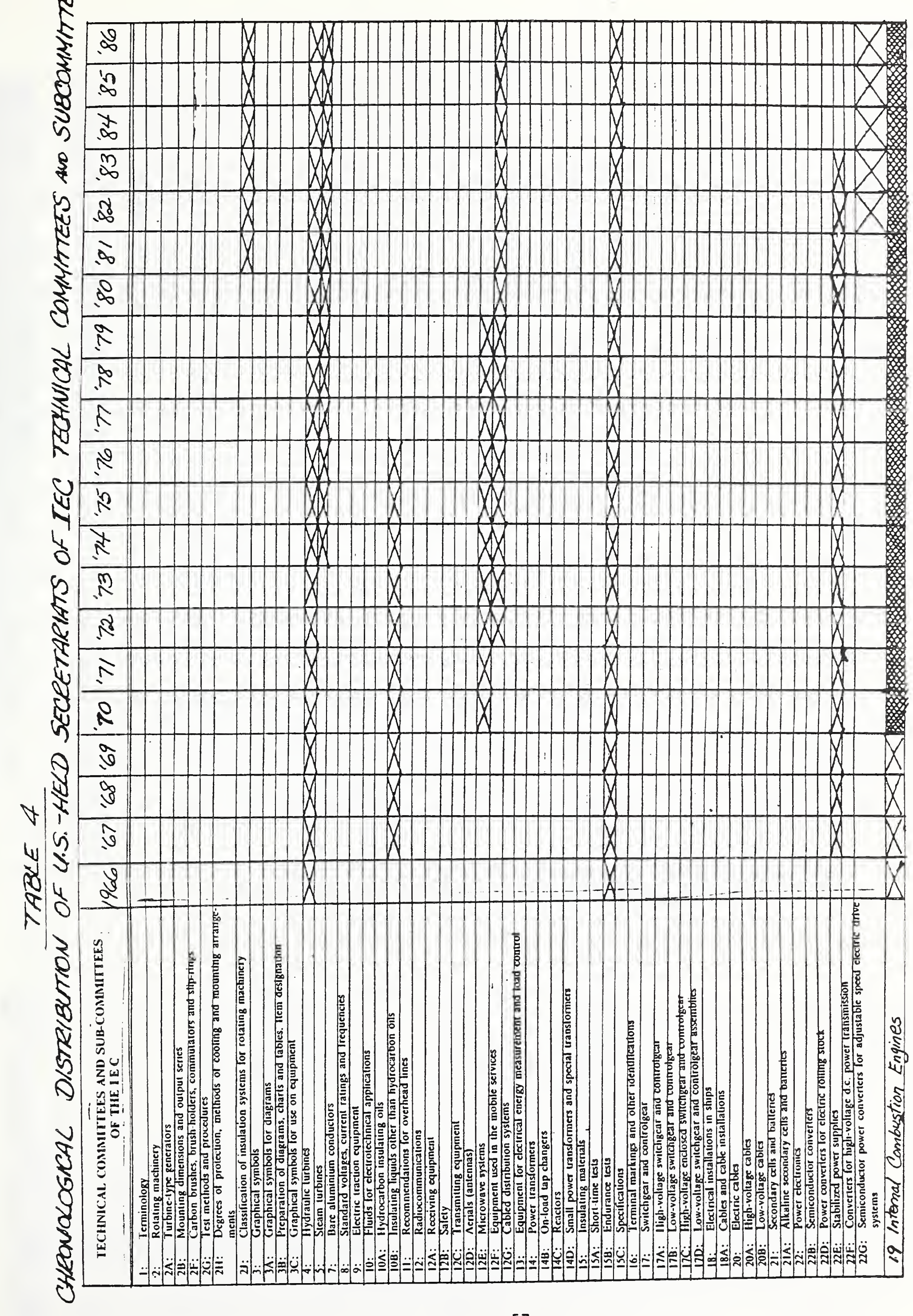




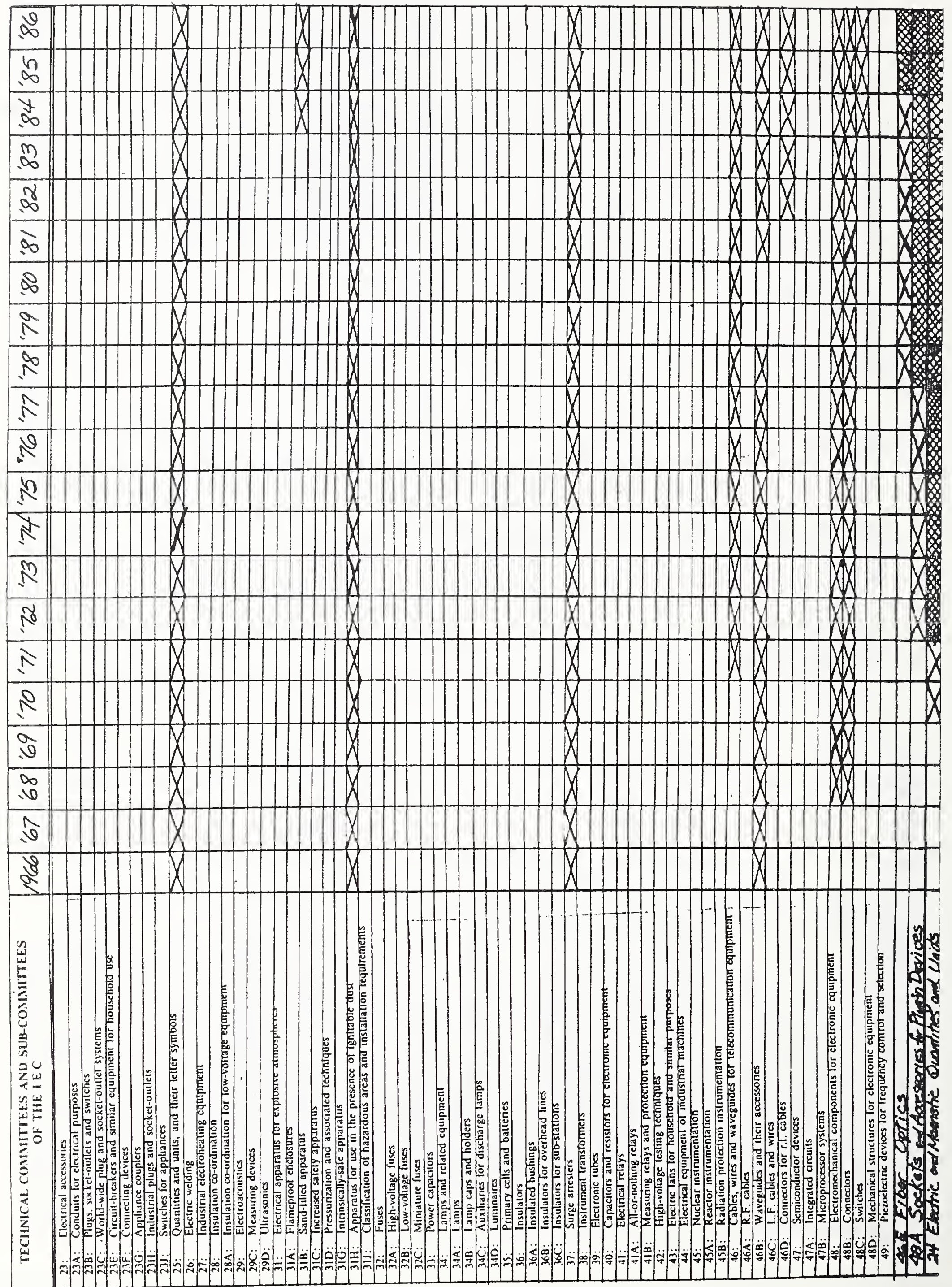




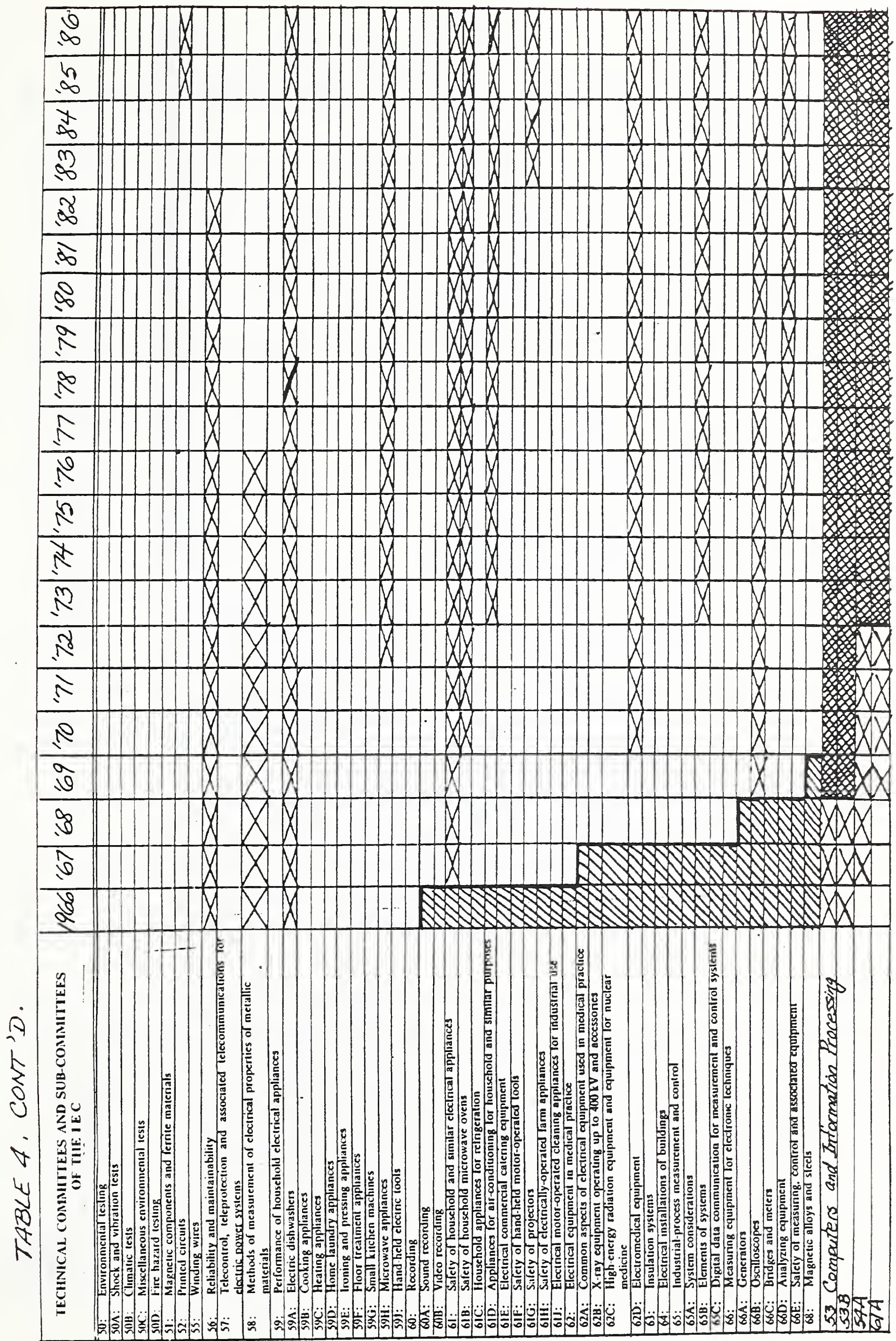




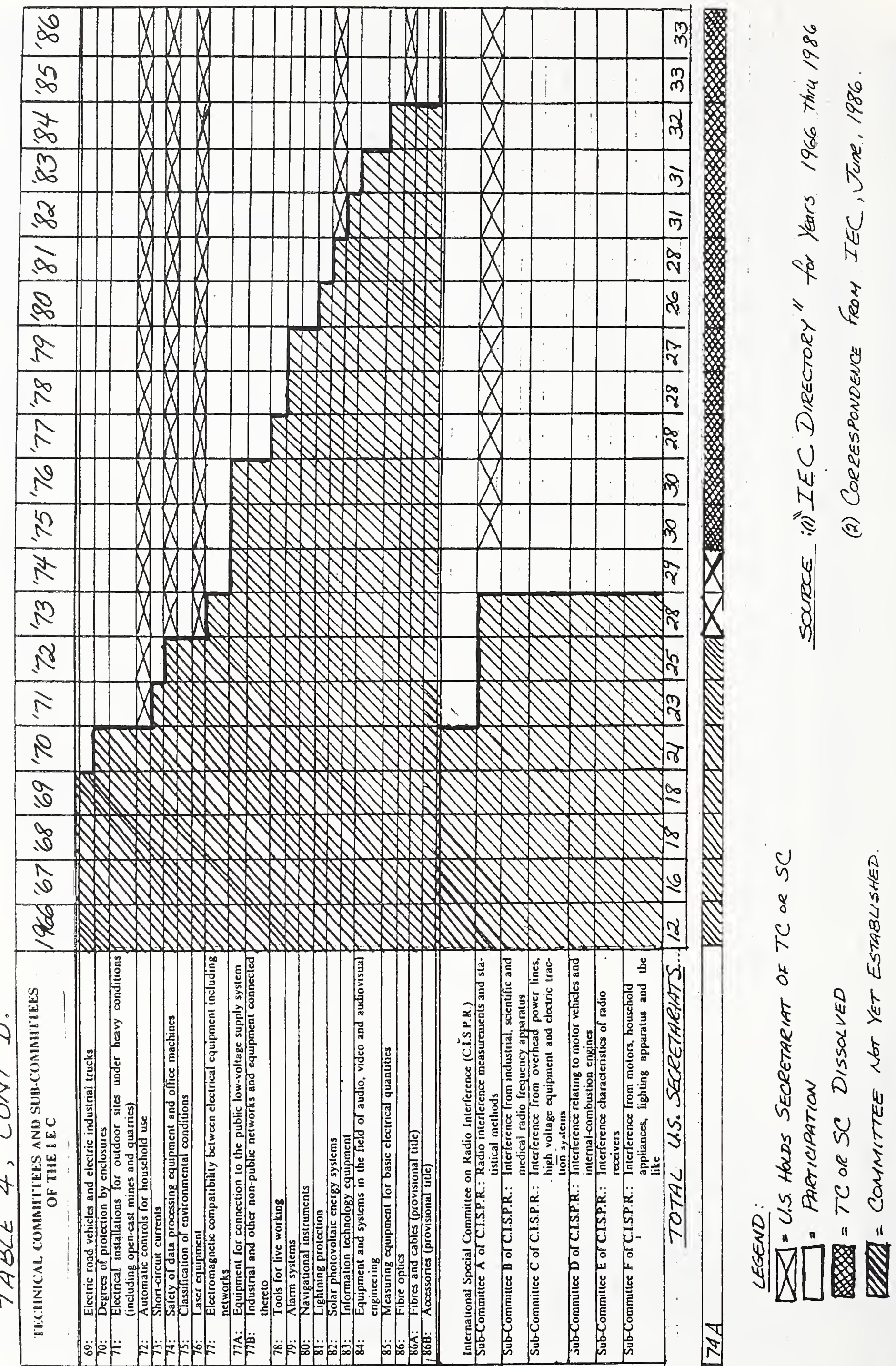


TABLE 5

LISTING OF INTERNATIONAL STANDARDS DIRECTLY ADOPTED

IN THE UNITED STATES AS "ANSI/ISO" STANDARDS

1. ANSI/ISO 5/1 - 1984, ANSI PH 2.16-1984, Terms, Symbols, and Notations - Density Measurements.

2. ANSI/ISO 5/2-1985, ANSI PH 2.19-1986, Density measurements-Geometric Conditions for Transmission Density.

3. ANSI/ISO 5/3 - 1984, ANSI PH 2.18-1985, Spectral Conditions.

4. ANSI/ISO5/4- 1983, ANSI PH 2.17-1985, Density Measurements, Geometric Conditions for Reflection Density.

5. ANSI/ISO 2240-1982, ANSI PH 2.21-1983, Method for Determining ISO Speed of Color Reversal Films.

6. ANSI/ISO 3028-1984, ANSI PH 2.28-1985, Camera Flash Illuminants - Determination of ISO Spectral Distribution Index.

7. ANSI/ISO 3334 - 1979, Microcopying - ISO Test Chart No. 2Description and Use in Photographic Documentary Reproduction.

8. ANSI/ISO 4341 - 1978, Magnetic Tape Cassette and Cartridge labeling and File Structure for Information Interchange.

9. ANSI/ISO 6053 - 1979, ANSI PH 3.107-1983, Snutter Cable Release Tip and Socket, Dimensions for.

10. ANSI/ISO 6328 - 1982, ANSI PH 2.33-1983, Determining the Resolving Power of Photographic materials, Method for.

11. ANSI/ISO 6728 - 1983, ANSI PH 3.607-1985, Camera LensesDetermination of ISO Colour Contribution Index.

12. ANSI/ISO 6846-1983, ANSI PH 2.2-1984, Black and Whitz Continuous Tone Papers - Determination of ISO Speed and Range for Printing.

13. ANSI/ISO 7187-1983, ANSI PH 2.47-1984, Direct Positive Color Print Camera Materials - Determination of ISO Speed.

14. ANSI/ISO 7589-1984, ANSI PH 2.29-1985, Illuminants for Photographic Sensitometry: Daylight and Incandescent Tungsten.

15. ANSI/ISO 8211 - 1985, Information Processing-Specification for Data Descriotive File for Information Interchange.

SOURCE: ANSI Catalog, 1987 


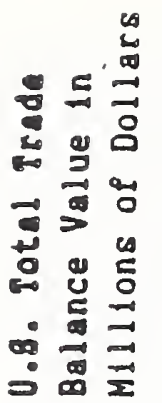

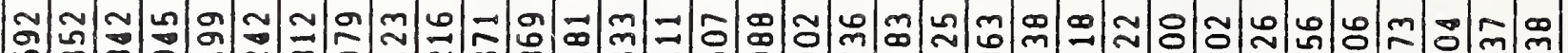
जู जी जो जो N N $1++$ -

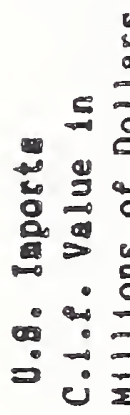

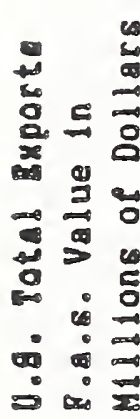

뭉

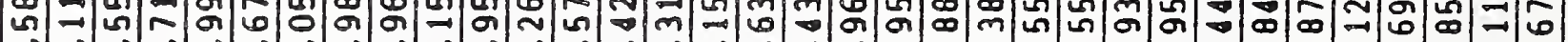
익 जो o $\stackrel{\sim}{\sim}$

gி

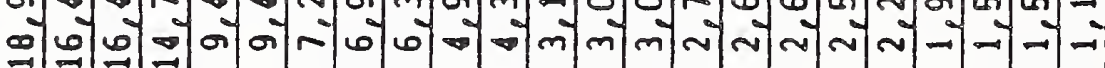

$\tilde{\omega}$

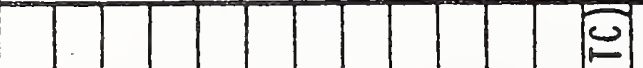

v

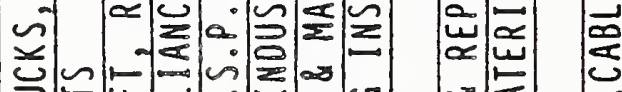

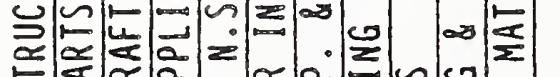

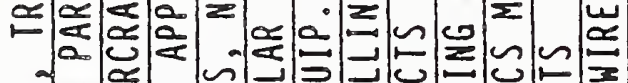

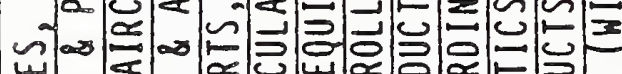

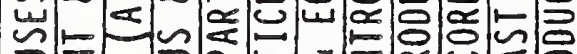

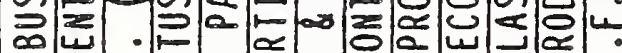

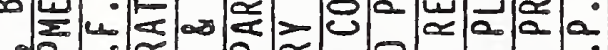

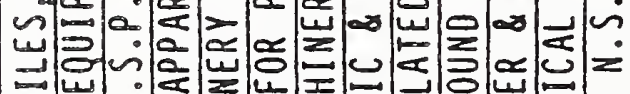

- 岕

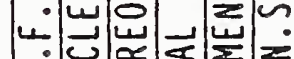

a $=\frac{1}{4}=$

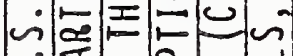

$\therefore \approx$ 正

a $\underset{\Xi}{\tilde{\sigma}} \approx$

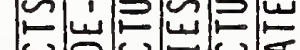

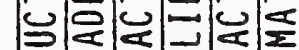

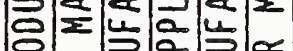

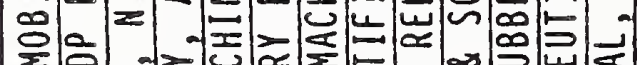

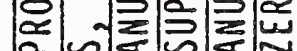

a $\sim 2 \approx$

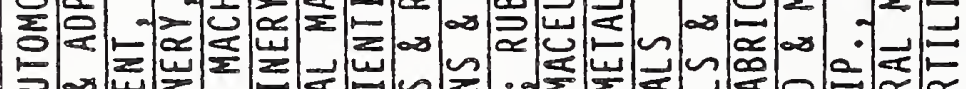

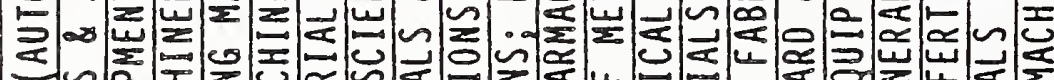

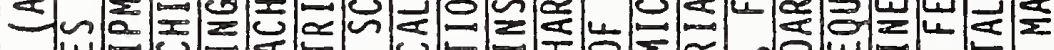

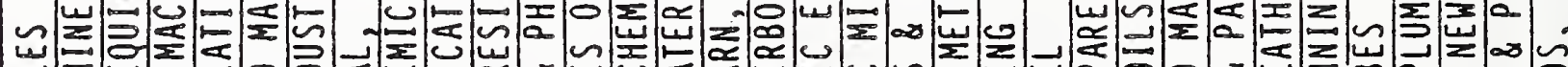
ప王 I

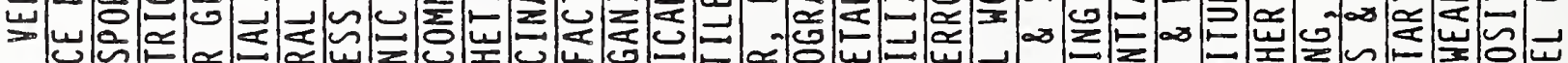

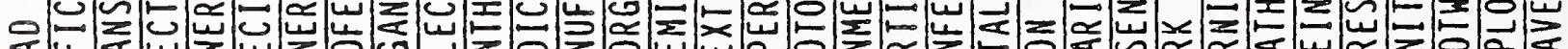

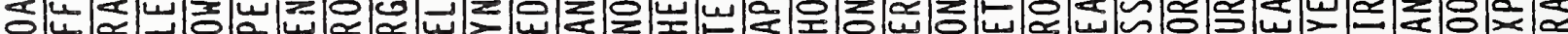

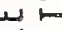

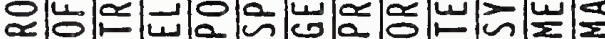
矛定㟔

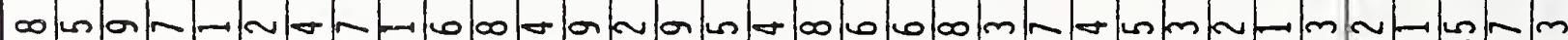




\begin{tabular}{|c|c|c|c|c|c|c|c|c|c|c|c|c|c|c|c|c|c|c|c|c|c|c|c|c|c|c|c|c|c|c|c|c|}
\hline & 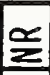 & & & & & & & & & & & & & & & & & 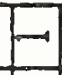 & & & & & & & & & & & & & & \\
\hline$\simeq$. & 0 & $\longrightarrow$ & & & & & $\sim$ & $m$ & - & $\sim$ & 0 & $\sim$ & $m$ & $\mapsto$ & & & $\longrightarrow$ & S & $\rightarrow$ & $\rightarrow$ & -1 & $\rightarrow$ & $\mapsto$ & 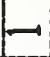 & to & -1 & $\square$ & $\rightarrow$ & & $\sim$ & - & \\
\hline$\therefore 0$ & $a$ & $\rightarrow$ & $m$ & $\sim$ & $\rightarrow$ & $m$ & תم & $\stackrel{0}{-1}$ & תم & $\sim$ & $m$ & $r$ & 100 & $\sigma$ & $\longrightarrow$ & - & $\sigma$ & $\infty$ & $\rightarrow$ & $\sigma$ & $\sigma$ & $m$ & $\hookleftarrow$ & $\mapsto$ & $\sim$ & & & & -1 & $m$ & & \\
\hline 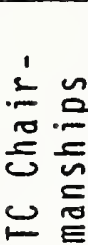 & $\begin{array}{l}\simeq \\
\infty \\
0 \\
0 \\
0\end{array}$ & 0 & $\rightarrow$ & 0 & 0 & 0 & $\rightarrow$ & $\sim$ & 0 & $\rightarrow$ & $\rightarrow$ & 0 & 10 & $\longrightarrow$ & 0 & 0 & 0 & $\rightarrow$ & 0 & 0 & 0 & 0 & 0 & 0 & 0 & 0 & 0 & 0 & -1 & 0 & 0 & \\
\hline
\end{tabular}

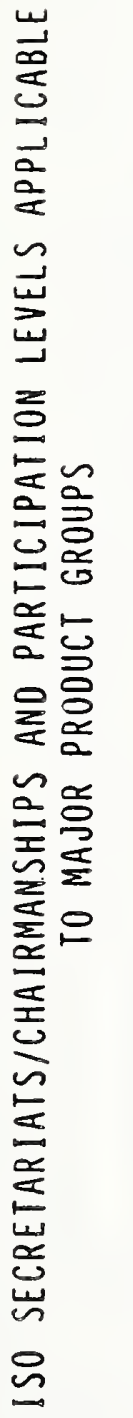

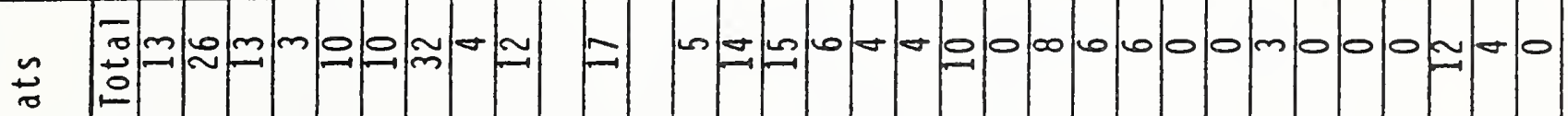

¿

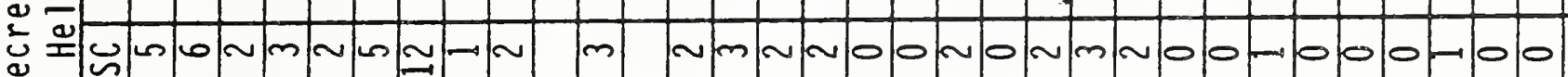

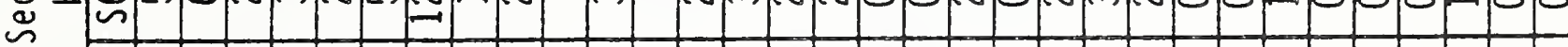

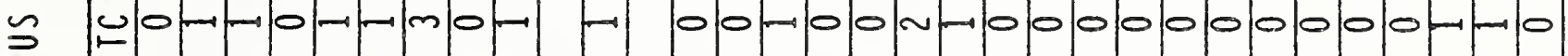

ت

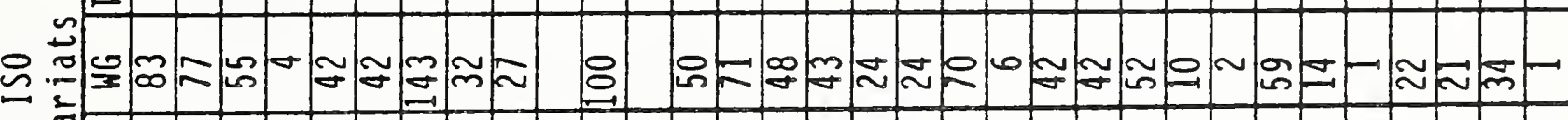
б 0 U 幽

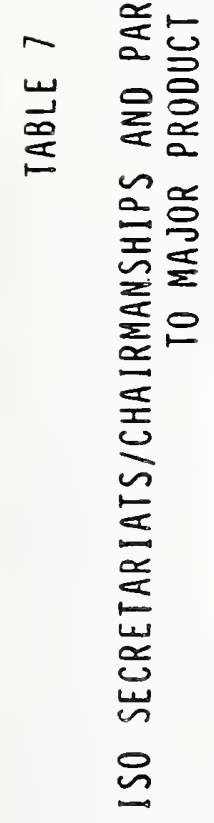

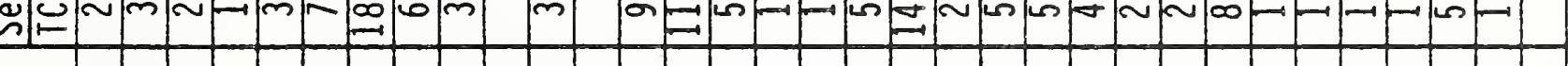

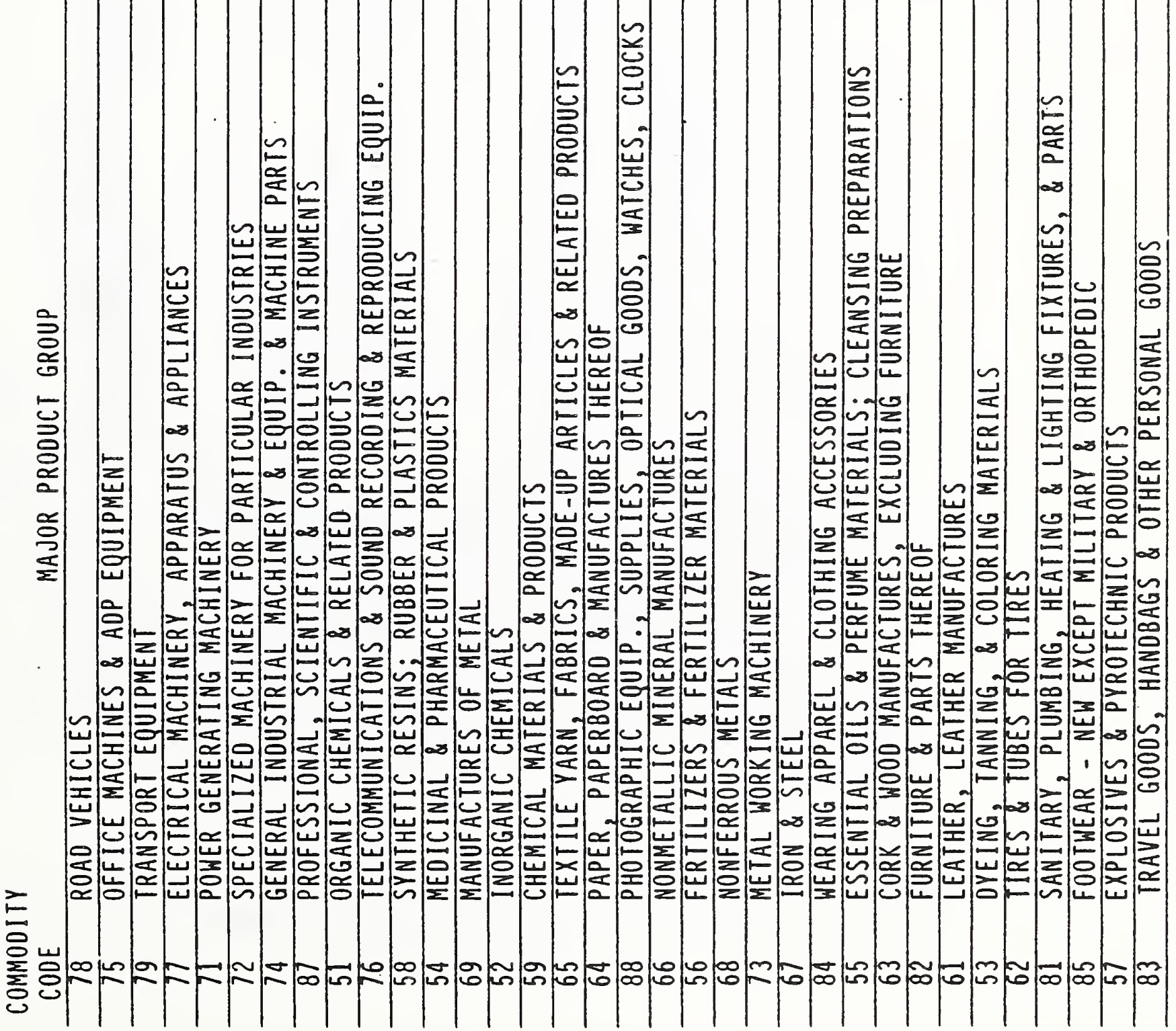




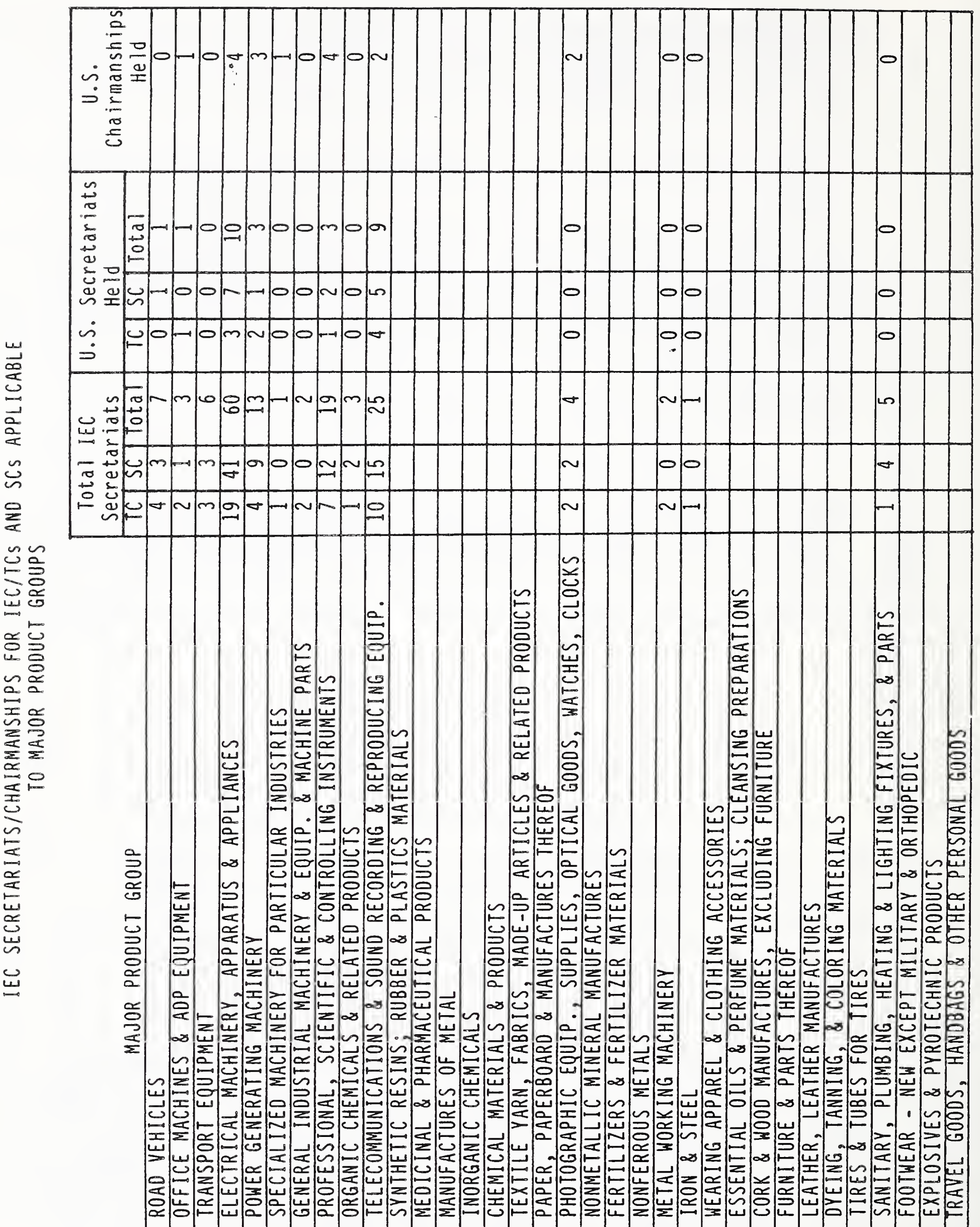

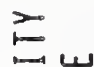

Б̈ 空 


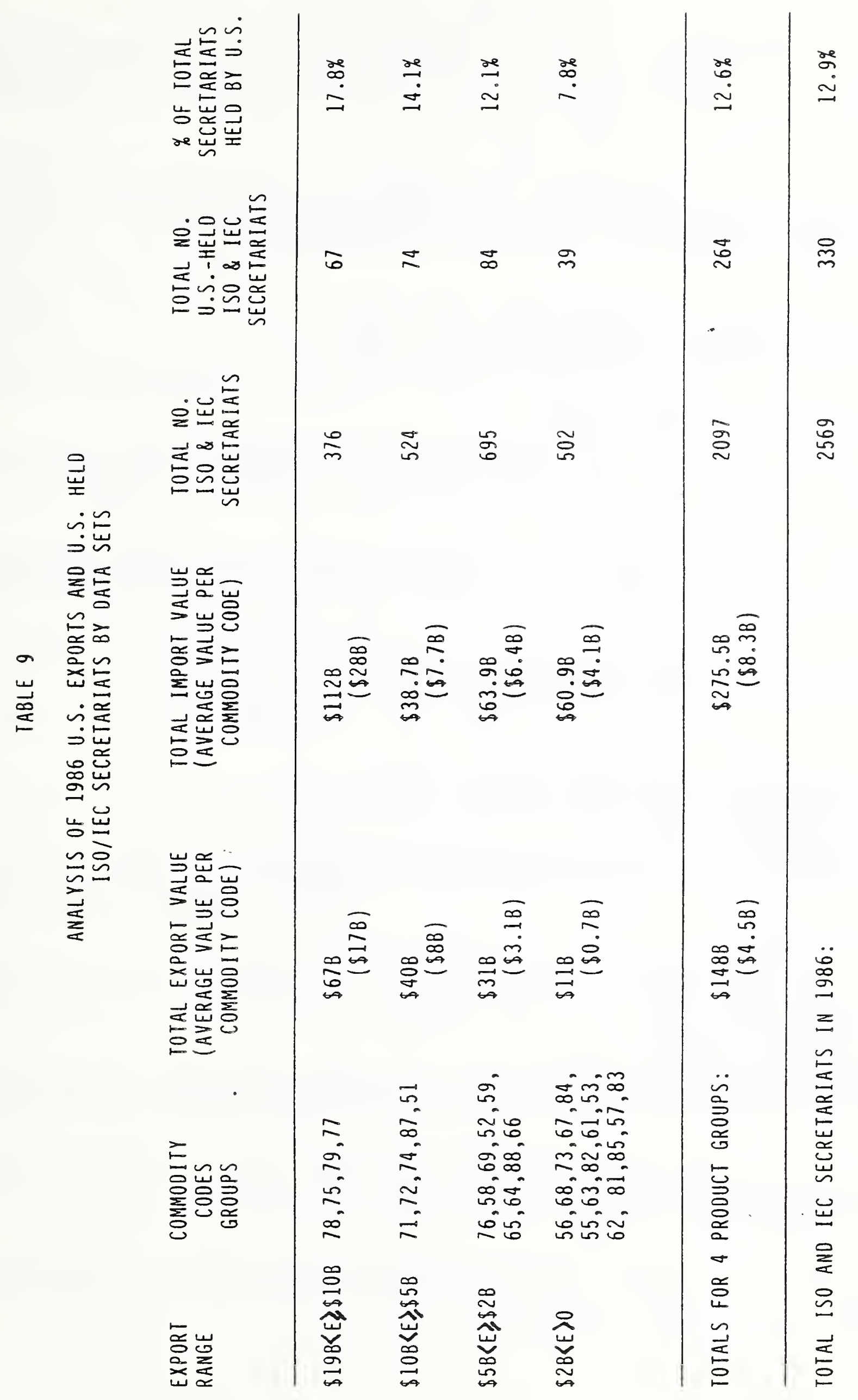


Breitenberg, Maureen A., editor, Directory of International and Regional Organizations Conducting Standards-Related Activities $(\mathrm{SP}-649)$, National Bureau of Standards, Gaithersburg, MD 20899, Apri 11983.

Cooke, Patrick W., Benefits Perceived by U.S. Industry From Participating in International Standards Activities (NBSIR 842886), National Bureau of Standards, Gaithersburg, MD 20899, September 1984 .

Cotrim, Alberto, "Standards Writing in Brazil," ASTM Standardization News, January 1987, p. 42.

Crane, Rhonda, J., The Politics of International Standards, Ablex Publishing, Norwood, NJ, 1979.

Fleckenstein, Donald C., Why IEC Support?, Presentation at ANSI Seminar, Arlington, VA, American National Standards Institute, New York, March 1987.

Gorton, Keith, et al, "The Use of ASTM Standards in International Trade" ASTM Standardization NewS, May and June 1984.

Hogan, Dorothy, "ANSI's Role in National and International Standardization," Standards Engineering, February 1386, pp. 4-5.

IEC Publications:

IEC Catalogue of Publications, 1987

IEC Directory, 1987

IEC Yearbook, 1987

International Electrotechnical Commission, Geneva 20 , Switzerland

ISO Publications:

ISO Catalogue, 1987

ISO Member Bodies, 1985 , 5 th edition

Iso Memento, 1987

ISO Participation, 1987

International Organization for Standardization, Geneva 20 Switzerland

Impact of International Standardization Trends on the U.S. Aerospace Industry, Aerospace Industries Association of America, Inc., Washington, D.C. $20030^{\circ}$, June 1982.

Leight, Walter G., editor, Proceeding of Conference on Standards and Trade (NBSIR 87-3573), National Bureau of Standards, Gaithersburg, MD 20899, June 1987 . 
Price, Gerald A., "Implementing International Standards on a Regional Basis," Proceedings of Joint Standards Engineering Society and International Federation for the Application of Standards Conference, Philadelphia, October 1986.

Ritterbusch, Gerald H., Why Support ISO?, Presentation at ANSI Seminar, Arlington, VA, American National Standards Institute, New York, March 1987.

Sturen, 011 e, Standards in the International Market, International organization for Standardization, Geneva 20 , Switzerland, 1984.

Sturen, 0lle, International Technology as Codified in Standards, International organization for Standardization, Geneva 20 , Switzerland, 1985.

Sturen, 011 e, International Standards Can Open Up New Markets, International organization for Standardization, Geneva 20 , Switzerland, September 1982 .

Strengthening U.S. Engineering Through International Cooperation: Some Recommendations for Action, National Academy of Engineering and Office of International Affairs, National Research Council, Washington, D.C., July 1987.

Toth, Robert B., editor, Standards Activities of Organizations in the United States (SP 58I), National Bureau of Standards, Gaithersburg, MD 20899, August 1984 .

Toth, Robert B., "Putting the U.S. Standards System into Focus with the world," ASTM Standardization News, December 1984.

Toth, Rodert B., International Standardization Trends Affecting Electric Utility Companies, Report prepared for Edison Electric Institute, November 1982.

United States Trade Performance in 1985 and Outlook, U.S. Department of Commerce, International Trade Administration, Washington, D.C., October 1986.

Vadelund, Eric A., editor, Proceedings of Conference on International Standards (NBSIR 85-3228), National Bureau of Standards, Gaithersburg, MD 20899, August 1985 . 
NBS. I14A (REV. 2-8C)

U.S. DEPT. OF COMM.

1. PUBLICATION OR REPORT NO

BIBLIOGRAPHIC DATA

SHEET (See instructions) NBSIR 88-3698

2. Performing Organ. Report Nod 3. Publication Date

4. TITLE AND SUBTITLE

A Review of U.S. Participation in International Standards Activities

5. AUTHOR(S)

Patrick W. Cooke

6. PERFORMING ORGANIZATION (If joint or other thon NBS, see insiructions)

7. ConeracuGrant No.

NATIONAL BUREAU OF STANDARDS

U.S. DEPARTMENT OF COMMERCE

GAITHERSBURG, MD 20899

9. SPONSORING ORGANIZATION NAME AND COMPLETE ADDRESS (Street, City, State, ZIP)

8. Type of Report \& Period Covered

10. SUPPLEMENTARY NOTES

Document describes a computer program: SF-185, FIPS Software Summary, is attached.

11. ABSTRACT (A 200-word or less foctual summory of most significant information. If document includes o significant bibliography or literature survey. mention it here)

This report describes the role of international standards, their increasingly significant importance in world trade, and the extent of past and current U.S. participation in the two major international standardization bodies; ISO and IEC. The degree of U.S. participation covers the 20 year period 1966 - 1986 . A coarse analysis of data indicates some correlation between U.S. participation and recent export performance for several major produst categories.

14. NO. OF PRINTED PAGES

X] Unlimited

For Official Distribution. Do Not Release to NTIS

Order From Superintendent of Documents, U.S. Government Printing Office, Washington, D.C. 20402.

Order From National Technical Information Service (NTIS), Springfield, VA. 2216I

\section{9}

15. Price 
- 
